\title{
Gabapentin improves colonic inflammatory damage and oxidative stress on acetic acid-induced colitis independent of cannabinoid pathway
}

Gabapentina melhora o dano inflamatório do cólon e o estresse oxidativo na colite induzida por ácido acético, independente da via canabinóide

Gabapentina mejora el daño inflamatorio del colon y el estrés oxidativo en la colitis inducida por ácido acético independiente de la vía de los cannabinoides

Received: 01/06/2021 | Reviewed: 06/07/2021 | Accept: 06/11/2021 | Published: 06/26/2021

Jalles Arruda Batista ORCID: https://orcid.org/0000-0001-8245-4185 Federal University of the Parnaíba Delta, Brazil E-mail: jalles_arruda@hotmail.com

Diva de Aguiar Magalhães ORCID: https://orcid.org/0000-0002-4888-8737 Federal University of the Parnaíba Delta, Brazil E-mail: divamagalhaes1@hotmail.com

Stefany Guimarães Sousa ORCID: https://orcid.org/0000-0003-0452-5122 Federal University of the Parnaíba Delta, Brazil E-mail: stefanyguimaraes@hotmail.com Tarcisio Vieira Brito ORCID: https://orcid.org/0000-0002-4802-2423 Federal University of the Parnaíba Delta, Brazil

E-mail: tarcisio_biohappy@hotmail.com

Carlos Eduardo Silva Monteiro ORCID: https://orcid.org/0000-0001-9033-2954 Federal University of Ceará, Brazil

E-mail: kadusilvamonteiro@hotmail.com

Nayonara Lanara Sousa Dutra ORCID: https://orcid.org/0000-0001-7083-4367 Federal University of the Parnaíba Delta, Brazil E-mail: nay.dutra_@hotmail.com

Cynthia Maria Carvalho Pereira ORCID: https://orcid.org/0000-0003-4218-6977 Federal University of the Parnaíba Delta, Brazil E-mail: cynthiamaria28@gmail.com

José Victor do Nascimento Lima ORCID: https://orcid.org/0000-0001-6627-5582 Federal University of the Parnaíba Delta, Brazil E-mail: n.victorlima19@hotmail.com

Ieda Figueira de Albuquerque ORCID: https://orcid.org/0000-0001-5015-8920 Federal University of the Parnaíba Delta, Brazil E-mail: ieda-figueira@ hotmail.com

Lauanda da Rocha Rodrigues ORCID: https://orcid.org/0000-0003-0333-8114 Federal University of the Parnaíba Delta, Brazil

E-mail: lauandarodrigues@hotmail.com.br Álvaro Xavier Franco ORCID: https://orcid.org/0000-0003-3600-7290 Federal University of Ceará, Brazil E-mail: alv_17@yahoo.com.br

Felipe Rodolfo Pereira da Silva ORCID: https://orcid.org/0000-0001-9224-5571 Federal University of the Parnaíba Delta, Brazil E-mail: feliperodolfo.15@ hotmail.com

Daniel Fernando Pereira Vasconcelos ORCID: https://orcid.org/0000-0002-3331-452X Federal University of the Parnaíba Delta, Brazil E-mail: vasconcelos@ufpi.edu.br 
André Luiz Reis Barbosa

ORCID: https://orcid.org/0000-0002-6452-9160 Federal University of the Parnaíba Delta, Brazil E-mail: andreluiz@ufpi.edu.br

\begin{abstract}
Objective: Gabapentin (GBP) possess a systemic anti-inflammatory action confirmed and endocannabinoids system have been effectives in reduces inflammatory disorders on intestinal tract. The aim of this study is evaluate the participation of the endogenous cannabinoids pathway in the anti-inflammatory and antioxidant effects of GBP in acetic acid (AA) induced colitis in mice. Methods: Colitis induction was performed using AA (6\%) and mice treated intraperitoneally with GBP or dexamethasone (subcutaneously) at $17 \mathrm{~h}$ or 17:30 $\mathrm{h}$ after induction of colitis, respectively. After $18 \mathrm{~h}$ of colitis induction, the animals were euthanized and colonic sample was taken for evaluation of macroscopic and microscopic lesion, wet weight and biochemical analyzes. Results: The administration of GBP was effective in reduce the macro and microscopic lesions, significant decreasing the colonic wet weight of colitis mice. The drug reduced the concentration myeloperoxidase (MPO), malondialdehyde (MDA) and interleukin 1 (IL-1) and increased the level glutathione (GSH) in colitis mice compared to normal mice. The treatment with endocannabinoids (ECs) receptors antagonists did not alter the GBP effect. Conclusion: Gabapentin was able to reduce inflammatory parameters in acid acetic-induced colitis, but its effect seems to be independent of cannabinoid pathway.
\end{abstract}

Keywords: Anti-inflammatory; Colitis; Inflammation; Antioxidant; Gastrointestinal tract; Gabapentin.

\title{
Resumo:
}

Objetivo: A gabapentina (GBP) possui ação antiinflamatória sistêmica confirmada e o sistema endocanabinoide tem sido efetivo na redução de desordens inflamatórias do trato intestinal. O objetivo deste estudo é avaliar a participação da via dos canabinóides endógenos nos efeitos antiinflamatórios e antioxidantes da GBP na colite induzida por ácido acético (AA) em camundongos. Métodos: A indução da colite foi realizada usando AA (6\%) e camundongos tratados intraperitonealmente com GBP ou dexametasona (por via subcutânea) 17 h ou 17:30 h após a indução da colite, respectivamente. Após $18 \mathrm{~h}$ da indução da colite, os animais foram submetidos à eutanásia e retirada de amostra colônica para avaliação macroscópica e microscópica da lesão, peso úmido e análises bioquímicas. Resultados: A administração de GBP foi eficaz na redução das lesões macro e microscópicas, diminuindo significativamente o peso úmido do cólon de camundongos com colite. A droga reduziu a concentração de mieloperoxidase (MPO), malondialdeído (MDA) e interleucina 1 (IL-1) e aumentou o nível de glutationa (GSH) em camundongos com colite em comparação com camundongos normais. O tratamento com antagonistas dos receptores endocanabinóides (ECs) não alterou o efeito do GBP. Conclusão: A gabapentina foi capaz de reduzir os parâmetros inflamatórios na colite induzida por ácido acético, mas seu efeito parece ser independente da via canabinóide.

Palavras-chave: Antiinflamatório; Colite; Inflamação; Antioxidante; Trato gastrointestinal; Gabapentina.

\section{Resumen}

Objetivo: La gabapentina (GBP) posee una acción antiinflamatoria sistémica confirmada y el sistema endocannabinoide ha sido eficaz para reducir los trastornos inflamatorios en el tracto intestinal. El objetivo de este estudio es evaluar la participación de la vía de los cannabinoides endógenos en los efectos antiinflamatorios y antioxidantes de la GBP en la colitis inducida por ácido acético (AA) en ratones. Métodos: La inducción de la colitis se realizó utilizando AA $(6 \%)$ y ratones tratados por vía intraperitoneal con GBP o dexametasona (por vía subcutánea) a las 17 ho 17:30 h después de la inducción de la colitis, respectivamente. Después de 18 h de inducción de colitis, los animales fueron sacrificados y se tomó una muestra de colon para evaluación de lesión macroscópica y microscópica, peso húmedo y análisis bioquímicos. Resultados: La administración de GBP fue eficaz para reducir las lesiones macro y microscópicas, disminuyendo significativamente el peso húmedo del colon de los ratones con colitis. El fármaco redujo la concentración de mieloperoxidasa (MPO), malondialdehído (MDA) e interleucina 1 (IL1) y aumentó el nivel de glutatión (GSH) en ratones con colitis en comparación con ratones normales. El tratamiento con antagonistas de los receptores de endocannabinoides (CEs) no alteró el efecto de GBP. Conclusión: La gabapentina fue capaz de reducir los parámetros inflamatorios en la colitis inducida por ácido acético, pero su efecto parece ser independiente de la vía de los cannabinoides.

Palabras clave: Anti-inflamatório; Colitis; Inflamación; Antioxidante; Tracto gastrointestinal; Gabapentina.

\section{Introduction}

Ulcerative colitis is a disease that exclusively involves the rectum and colon (Khor, Gardet \& Xavier, 2011). It is characterized by idiopathic inflammation that usually occurs in the superficial layer of the intestinal wall, in the mucosa and submucosa, presenting abscesses in the crypts, infiltration of neutrophilic cells and superficial ulcerations, edema, epithelial necrosis and hemorrhage commonly occur (Robbins, 2012). For not knowing the nature of the initial stimulus, as well as the 
exact mechanisms of the pathogenesis, the treatment currently used is basically directed to pharmacological modulation of these constant inflammatory and immune responses that have escaped the control of the individual defense mechanisms (Podolsky, 1991).

Ulcerative colitis possess a triad of factors pathophysiology; genetic component since the most important risk factor is a family history of the disease ( $8 \%$ to $14 \%$ of patients); alterations in the composition of the gut microbiota and defects in mucosal immunity, autoimmunity may also play an important role in the etiology of ulcerative colitis (Lynch \& Hsu, 2020).

Despite the large number of anti-inflammatory drugs currently available for clinical use, there are still no antiinflammatory drugs with greater specificity and reduced adverse effects. Gabapentin (GBP) has been shown to have a high pharmacological potential against inflammatory conditions and at low doses causes little adverse effect (Dias et al, 2014). The data above have drawn our interest in investigating whether GBP regulates the inflammatory bowel process on an experimental model of colitis (Marquéz et al, 2009).

Gabapentin (1-aminomethyl-cyclohexane acetic acid), developed for the treatment of epilepsy, has been used in clinical practice for the treatment of neuropathic pain (Arendt-Nielsen et al, 2007). Its mechanism of action seems to involve the binding to $\alpha_{2} \delta$-1 and $\alpha_{2} \delta$-2 auxiliary subunits of calcium channels (Hoppa, Lana, Margas, Dolphin \& Ryan, 2012). This drug can also reverse the gastric inflammatory damage induced by indomethacin and ethanol (Abdel-Salam \& Sleem, 2009). This drug can also reverse the gastric inflammatory damage induced by indomethacin and ethanol and the anti-inflammatory effect of GBP appears to be mediated by inhibiting neutrophil infiltration at the inflammatory site as well as inhibiting the release or activity of inflammatory mediators (Dias et al, 2014). A recent study showed that the drug possesses a systemic antiinflammatory action by decreasing the release of cytokines and reducing oxidative stress in vivo (Dias et al, 2014).

In addition to the effects of GBP, there are other mechanisms of action that may act on the inflammatory response in the gastrointestinal tract, including the endocannabinoid system pathway that is involved in pathophysiological processes such as pain, inflammation, appetite, reproduction and cardiovascular system (Klein et al, 2003). In experimental models of inflammatory bowel disease in animals, increased participation of the ECs pathway is observed and increased expression of cannabinoids receptors occurs in the colon and ileum of humans (Ihenetu, Molleman, Parsons \& Whelan, 2003).

The ECs system has an important role in the maintenance of gut homeostasis and the modulation of this system in murine colitis has attenuated the inflammation (Salaga et al, 2014). Anandamide (endogenous agonist) levels are high in the inflamed colon of patients with ulcerative colitis, calling for a pharmacological strategy (Storr et al, 2009). Animals with a genetic deficiency of endocannabinoids (ECs) receptors and treated with cannabinoids (CBs) antagonist developed more severe colitis (Massa et al, 2004).

Emerging evidence suggests that cannabinoids may exert beneficial effects in intestinal inflammation. Adaptive changes of the endocannabinoid system has be observed in intestinal biopsies from patients with inflammatory bowel disease (Izzo \& Camilleri, 2009).

Endocannabinoid system, though the activation of the cannabinoid 1 receptor (CB1R), plays a very relevant role in reducing NMDAR activity, this mechanism causes a decrease in neuronal excitability as well as a decrease in the pain impulse (Rodríguez, Sánchez, Merlos \& Garzón, 2016). Gabapentin also acts on NMDA receptor and is frequently used by the clinic for the treatment of neuropathic pain (Taylor \& Harris, 2020). Evidence points also that, peroxisome proliferator-activated receptors, PPARs modulate the activity of endocannabinoids receptors (O'Sullivan, 2016). In addition, GBP exerts its intestinal anti-inflammatory activity by activating the PPAR-gamma receptor (de Brito et al, 2020). For these reasons, we believe that GBP may also have some relationship with other CBs. 
The involvement of the EC systems and GBP action in various physiological and pathological process results provides evidence for this work that aims to demonstrate the pharmacological potential of GBP in AA-induced ulcerative colitis by studying the possible involvement of the ECs receptors type 1 (CB1: AM 251) and type 2 (CB2: AM 630).

\section{Materials and Methods}

\subsection{Characteristic of the methodology}

The present study is a scientific laboratory research with qualitative and quantitative characteristics. The data obtained in this study are the results of strictly controlled experiments, which have a high degree of originality and reliability, the numerical results; complement the qualitative data, which are satisfactory to support our hypothesis (Pereira, et al., 2018).

\subsection{Animals and ethical guidelines}

Male swiss mice $(25-30 \mathrm{~g})$ obtained from the Federal University of Piauí (UFPI) were housed at $25 \pm 2{ }^{\circ} \mathrm{C}$ under a $12 / 12 \mathrm{~h} \mathrm{light/dark}$ cycle. The animals were deprived of food and free access to water for $15 \mathrm{~h}$ prior to the experiment. Experiments were conducted in accordance with COBEA and approved by the Ethics Committee of the Federal University of Piauí (Protocol № 001/18).

\subsection{Colitis induction}

Colitis induction was performed according to Guazelli et al. (2013) (Guazelli, Fattori, Colombo \& Georgetti, 2013) with modifications. The animals were anesthetized with ketamine $(80 \mathrm{mg} / \mathrm{kg})$ and xilazin $(10 \mathrm{mg} / \mathrm{kg})$ intraperitoneally (i.p.). The colitis was induced by intrarectal administration $(200 \mu \mathrm{L})$ of AA $(6 \%)$ dissolved in saline solution. After $18 \mathrm{~h}$, the animals were euthanized with a lethal dose of ketamine $(240 \mathrm{mg} / \mathrm{kg})$ and xylazine $(30 \mathrm{mg} / \mathrm{kg})$ to remove colonic tissue.

\subsection{Colitis experimental model for GBP treatment}

The animals were divided into six groups ( $\mathrm{n}=6$ /group): Group 1 received intracolon saline solution $(200 \mu \mathrm{L})$; Group 2 received only intracolonic AA 6\%; After 17 hours of induction of colitis, groups 3, 4 and 5 received AA 6\% + GBP $(0.1,0.3$ and $1.0 \mathrm{mg} / \mathrm{kg}$, respectively); $30 \mathrm{~min}$ before euthanasia, group 6 received AA $6 \%+$ dexamethasone $(2.0 \mathrm{mg} / \mathrm{kg})$. Subsequently, tissue samples from the colon were collected to evaluate macroscopic and microscopic parameters, wet weight and biochemical analyses. We also assessed the participation of endocannabinoid receptors on the anti-inflammatory effect of GBP during AA-induced colitis.

For that evaluation, the animals received intracolon solutions of saline and AA 6\%, as well as AA $6 \%+$ GBP $(0.1$ $\mathrm{mg} / \mathrm{kg}$ i.p. plus AM $2510.3 \mathrm{mg} / \mathrm{kg}$ i.p. or plus AM $6301.0 \mathrm{mg} / \mathrm{kg}$ i.p.). GBP was co-administered $17 \mathrm{~h}$ after colitis induction, and cannabinoid receptor antagonists $17 \mathrm{~h} 30 \mathrm{~min}$ after induction of colitis. Subsequently, analysis of inflammatory parameters and biochemical analyses were performed.

\subsection{Colon macroscopic lesion scores analysis}

The colon $5 \mathrm{~cm}$ was removed in which it was opened longitudinally and washed with physiological solution. Subsequently, macroscopic lesion scores were established using specific criteria (Morris et al, 1989) with modifications. The established criteria were: no damage (score 0); localized hyperemia but no ulcers (score 1); linear ulcers without significant inflammation (score 2); linear ulcers with inflammation in one place (score 3); two or more sites of ulceration and inflammation (score 4); a site of inflammation $>1 \mathrm{~cm}$ along the length of the colon (score 5); local 
inflammation $>2 \mathrm{~cm}$ along the length of the colon, with quantification increased to 1 for each additional centimeter (score 6 $10)$.

\subsection{Colon wet weight of animal measurement}

The distal segments of the colon were sectioned, measuring $5 \mathrm{~cm}$, to determine the moist weight of the colon. Results were expressed ( $\mathrm{g} / 5 \mathrm{~cm}$ colon) of colitis animals, and were compared with a normal control group (no colitis) and in relation for animals treated with different doses of GBP (Brito et al, 2016).

\subsection{Histopathological analysis}

In the evaluation of the histological parameters, tissue samples from the colon were fixed in $10 \%$ formalin solution for a period of 24 hours, in which they were then transferred to $70 \%$ alcohol solution. Subsequently, the intestinal segment was immersed in paraffin, sectioned, deparaffinized, stained with hematoxylin and eosin and analyzed under a microscope (blind analysis). The evaluation had as reference criteria the following parameters: loss of mucosal architecture (0-3 score), cell infiltration (score 0-3), muscle thickening (score of 0-3), crypt abscess (score of 0 -1) and depletion of goblet cells (score of 01) (Appleyard \& Wallace, 1995). This evaluation was performed by a reference histopathologist.

\subsection{GSH assay}

The colon samples were homogenized in $0.02 \mathrm{M}$ EDTA $(1 \mathrm{~mL} / 100 \mathrm{mg}$ tissue). Subsequently, $400 \mu \mathrm{L}$ of homogenate were mixed with $300 \mu \mathrm{L}$ of distilled water and $80 \mu \mathrm{L}$ of trichloroacetic acid $(50 \%$, w/v) and centrifuged at $3000 \mathrm{rpm}$ for 15 minute. Then, $400 \mathrm{ml}$ of supernatant was mixed with $800 \mathrm{ml}$ of Tris buffer (0.4M, pH: 8.9) and $20 \mathrm{ml}$ of $0.01 \mathrm{M}$ DTNB was added, and the samples were subsequently stirred for a period of 3 minute. A reading spectrophotometer with absorbance adjustment measured at $412 \mathrm{~nm}$ was used. The results are expressed as $\mu \mathrm{g}$ of GSH/g tissue (Sedlak \& Lindsay, 1968).

\subsection{MDA assay}

Colon intestinal tissue samples were homogenized in $1.15 \% \mathrm{KCl}(1 \mathrm{~mL} / 100 \mathrm{mg}$ tissue $) .250 \mathrm{ml}$ of the homogenate was added in $1.5 \mathrm{ml}$ of $\mathrm{H} 3 \mathrm{PO} 4(1 \%)$ and $0.5 \mathrm{ml}$ of an aqueous solution of aqueous thiobarbituric acid (0.6). The tubes were heated for 45 minutes in a boiling water bath and the reaction mixture was then cooled in an ice-water bath, followed by the addition of $2 \mathrm{ml}$ of n-butanol. The contents were mixed for $1 \mathrm{~min}$. with a vortex mixer, centrifuged and the absorbance of the organic layer was measured at 520 and $535 \mathrm{~nm}$. The results were expressed as mmol of MDA/g of tissue (Mihara \& Uchiyama, 1978).

\subsection{MPO activity assay}

The extent of neutrophil accumulation in colon tissue was measured indirectly by the enzymatic levels of MPO (Silva et al, 2013). 50 to $100 \mathrm{mg}$ of tissue were homogenized in $1 \mathrm{ml}$ of potassium buffer with $0.5 \%$ hexadecyltrimethylammonium bromide per $50 \mathrm{mg}$ of tissue. The homogenate was centrifuged at $40,000 \mathrm{x} \mathrm{g}$ for $7 \mathrm{~min}$ at $4{ }^{\circ} \mathrm{C}$ and the supernatant analyzed by spectrophotometry to determine the MPO activity at $450 \mathrm{~nm}$. The results were expressed as the MPO units per milligram of tissue of the colon.

\subsection{Cytokines assay}

Colon samples were homogenized in sterile saline and levels of IL-1 $\beta$ interleukin in the colon samples were determined by the Enzyme-Linked Immunoabsorbent Assay (ELISA) kit according to the recommendations of the 
manufacturer (Tavares-Murta, de Resende, Cunha \& Murta, 2008). The results were expressed in picograms per milliliter of homogenate $(\mathrm{pg} / \mathrm{ml})$.

\subsection{Statistical Analysis}

Results are expressed as mean \pm SEM and five animals per group. Statistical analysis was performed using analysis of variance (ANOVA) followed by the Newman-Keuls post-hoc test. The histopathological parameters were analyzed using the Kruskal-Wallis nonparametric test, followed by a multiple comparisons with Dunn's test. $p<0.05$ was considered statistically significant.

\section{Results}

\subsection{GBP reduces macroscopic scores of lesions on colitis by AA}

As seen in Figure 1A, the colitis induction by intracolonic administration of AA in mice showed a significant increase $(\mathrm{p}<0.05)$ in lesion macroscopic scores $(17.60 \pm 1.60)$ compared to the group that received only intracolonic saline $(0.57 \pm$ 0.20). Already the mice treated with GBP at doses $0.1 \mathrm{mg} / \mathrm{kg}, 0.3 \mathrm{mg} / \mathrm{kg}$ or $1.0 \mathrm{mg} / \mathrm{kg}$, presented injury scores: (20.0 \pm 1.30 ); $(15.8 \pm 2.30)$ and $(4.00 \pm 1.09)$ respectively. Dose at $1.0 \mathrm{mg} / \mathrm{kg}$ there was a significant decrease in macroscopic lesion scores in relation to the AA colitis group. As expected, the group treated with dexamethasone (Dexa) in the dose of $2.0 \mathrm{mg} / \mathrm{kg}$ also showed a decrease in the macroscopic scores $(4.80 \pm 0.73)$ compared to the colitis AA group.

\subsection{GBP reduces wet weight of colon injured by $\mathrm{AA}$}

According to Figure 1B, acetic acid intracolonic administration in mice promoted a significant $(\mathrm{p}<0.05)$ increase in the colon-wet weight $(0.38 \pm 0.02 \mathrm{~g} / 5 \mathrm{~cm})$ when compared to saline group $(0.21 \pm 0.01 \mathrm{~g} / 5 \mathrm{~cm})$. However, when these animals were treated with GBP at the dose of $1.0 \mathrm{mg} / \mathrm{kg}$, they presented a significant decrease in the wet weight $(0.21 \pm 0.01 \mathrm{~g} / 5 \mathrm{~cm})$ compared to AA colitis group. Similarly, the group treated with Dexa $2.0 \mathrm{mg} / \mathrm{kg}$ also reduced colon wet weight $(0.29 \pm 0.02$ $\mathrm{g} / 5 \mathrm{~cm}$ ) compared to AA colitis group ( $\mathrm{p}<0.05$ ). 
Figure 1. Macroscopic lesion scores (A) and wet weight (B) in the colon of the animals were measured using criteria established by Morris and Brito, respectively. Animals with colitis were treated by GBP at doses $(0.1,0.3 \mathrm{and} 1.0 \mathrm{mg} / \mathrm{kg}$, ip) and Dexamethasone. The results were expressed as mean \pm SEM of the sum of the obtained scores. \# P $<0.05$ vs saline group, $* \mathrm{p}<0.05$ vs AA group. Statistical analysis was performed using the ANOVA variance test followed by the Newman-Keuls test.
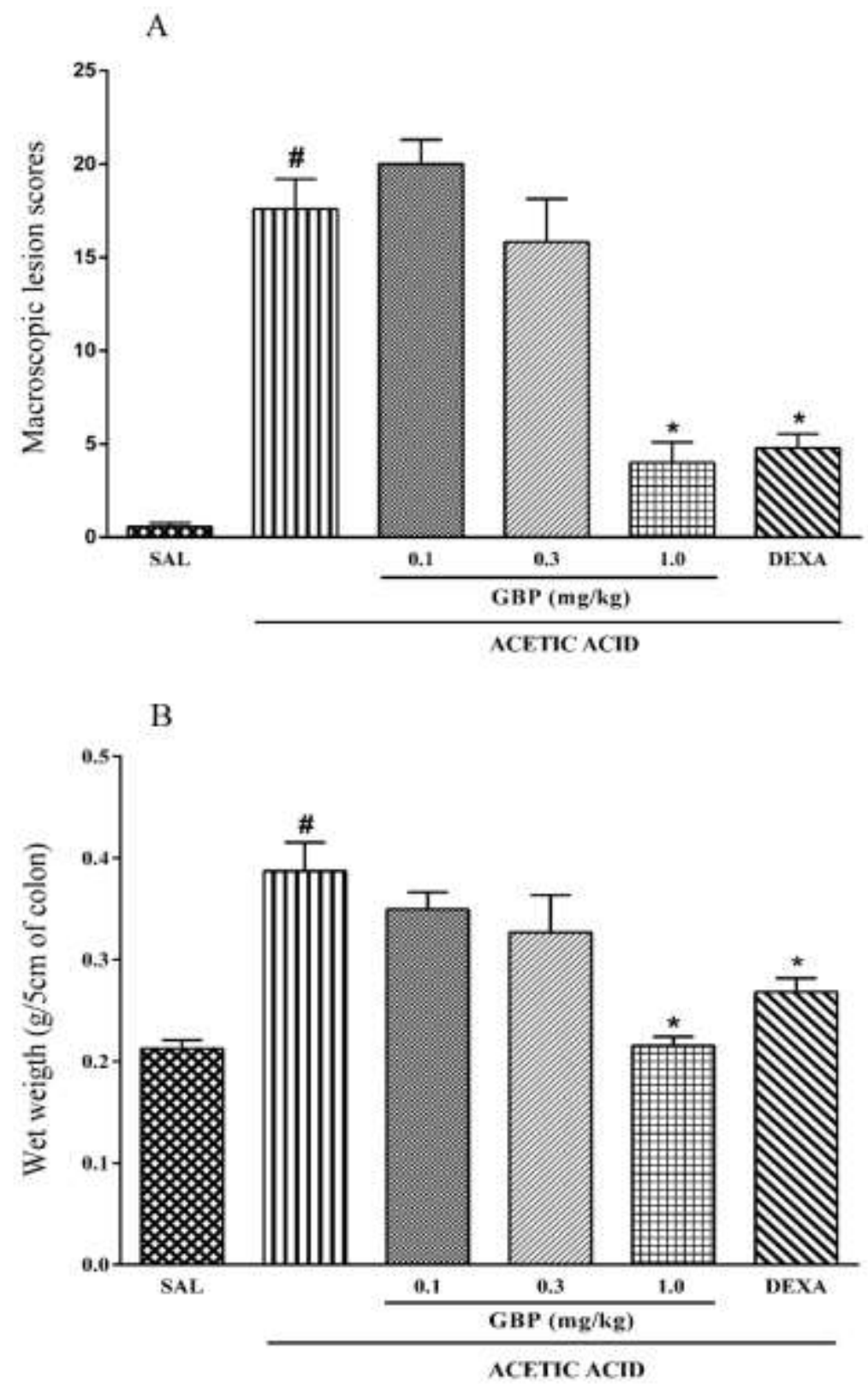

Source: Authors (2021).

In this figure, it is important to note the potential of GBP to reverse the inflammatory parameters observed in both macroscopic scores (A) and wet weight (B). 


\subsection{GBP decreases colon tissue histopathological damages}

As shown in Table 1 and Figure 2B, intracolonic AA administration promoted loss of mucosal architecture, intense cell infiltration, crypt abscess formation and goblet cell depletion, with microscopic scores totaling 11 (10-11) compared to saline group, $0(0-0)$. On the other hand, the group treated with GBP $(1.0 \mathrm{mg} / \mathrm{kg}$, i.p. $)$ showed diminished significantly $(\mathrm{p}<0.05)$ of the microscopic scores $1(0-3)$, (as in Table 1, Figure 2C) compared to AA colitis group. As expected, Dexa also reduced microscopic score 3 (0-3) (Table 1, Figure 2D).

Table 1. GBP effect on histopathological criteria of intestinal lesion caused by acetic acid-induced colitis in mice.

Histological lesion scores expressed as mean \pm error $(n=5-6)$. Non-parametric Kruskal-Wallis test followed by the Dunn test. \# $\mathrm{P}<0,05$ when compared to saline.

$* \mathrm{P}<0,05$ when compared to the control group (AA).

\begin{tabular}{lcccccc}
\hline Groups & $\begin{array}{c}\text { Loss of } \\
\text { architecture } \\
(\mathbf{0 - 3})\end{array}$ & $\begin{array}{c}\text { Cellular } \\
\text { infiltration } \\
(\mathbf{0 - 3})\end{array}$ & $\begin{array}{c}\text { Muscle } \\
\text { thickening } \\
(\mathbf{0 - 3})\end{array}$ & $\begin{array}{c}\text { Crypt abscess } \\
(\mathbf{0 - 1})\end{array}$ & $\begin{array}{c}\text { Goblet cell } \\
\text { depletion } \\
(\mathbf{0 - 1})\end{array}$ & $\begin{array}{c}\text { Total score of } \\
\text { damage } \\
(\mathbf{0 - 1 1})\end{array}$ \\
\hline Saline & $0(0-0)$ & $0(0-0)$ & $0(0-0)$ & $0(0-0)$ & $0(0-0)$ & $0(0-0)$ \\
AA & $3,0(3-3) \#$ & $3,0(2-3) \#$ & $3,0(2-3) \#$ & $1(1-1) \#$ & $1(1-1) \#$ & $11(9-11) \#$ \\
AA + GBP & $0(0-1)^{*}$ & $0(0-1)^{*}$ & $0(0-1)^{*}$ & $0(0-0)^{*}$ & $0(0-0)^{*}$ & $0(0-3)^{*}$ \\
AA + DEXA & $1(0-1)^{*}$ & $1(0-1)^{*}$ & $1(0-1)^{*}$ & $0(0-0)^{*}$ & $0(0-0)^{*}$ & $3(0-3)^{*}$ \\
\hline
\end{tabular}

Source: Authors (2021).

In this table, it is important to note the decrease in histopathological scores of lesions caused by the action of gabapentin. 
Figure 2. Microphotography (200x, $50 \mu \mathrm{m}$ scale) representing the GBP anti-inflammatory effect on intestinal damage induced by AA in mice. Saline solution (A); AA (B); GBP (C); Dexamethasone (D). Red arrows: architecture of the mucosa (villi and crypts); yellow arrows: cellular infiltration; black arrows: muscular thickening.
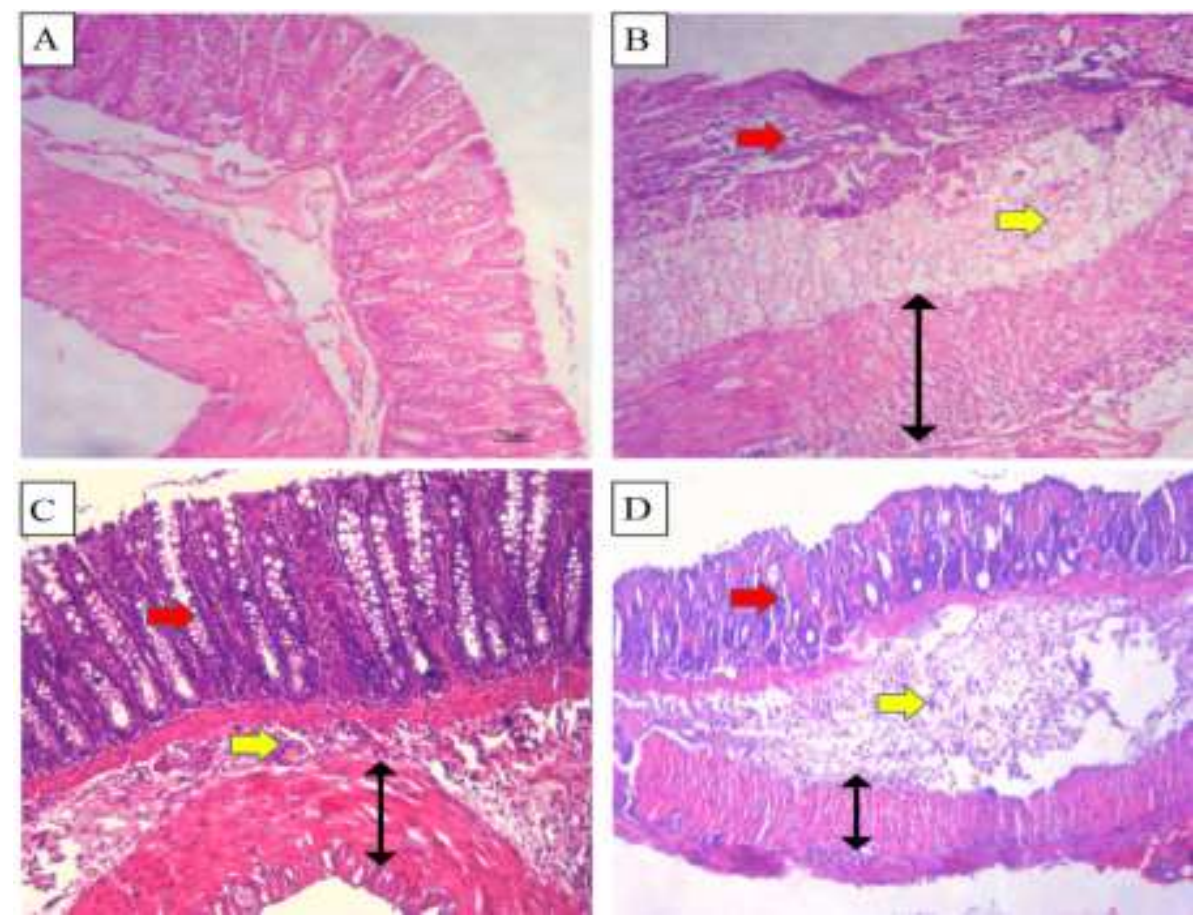

Source: Authors (2021).

In the figure above, it is important to observe the decrease in histopathological damage caused by gabapentin. Note carefully that in (B) the acetic acid group brings a complete disorganization of the tissue structure, whereas in (C) it is clear the occurrence of a more evident tissue organization.

\subsection{GBP decrease MPO activity}

The colitis group showed a significant $(\mathrm{p}<0.05)$ increase in MPO level $(39.33 \pm 3.09 \mathrm{UMPO} / \mathrm{mg}$ of colon tissue) compared to the saline group $(2.48 \pm 0.49 \mathrm{UMPO} / \mathrm{mg}$ tissue). The administration of $1.0 \mathrm{mg} / \mathrm{kg}$ of GBP reduced (p $<0.05)$ the level of this enzyme $(4.04 \pm 0.54 \mathrm{UMPO} / \mathrm{mg}$ of colon tissue) compared to the colitis group (Figure $3 \mathrm{~A}$ ).

\subsection{GBP decrease IL-1ß levels in colonic tissue}

A significant $(\mathrm{p}<0.05)$ increase in IL-1 $\beta$ levels was observed in the colitis group $(3.58 \pm 0.07 \mathrm{pg} / \mathrm{mL})$ compared to the saline group $(1.73 \pm 0.14 \mathrm{pg} / \mathrm{mL})$. Administration of GBP at the dose of $1.0 \mathrm{mg} / \mathrm{kg}$ significantly reduced the concentration of IL-1 $\beta(2.51 \pm 0.23 \mathrm{pg} / \mathrm{mL})$ compared to the colitis group (Figure $3 \mathrm{~B}$ ). 
Figure 3. GBP reduced MPO (A) concentrations and IL-1 $\beta$ (B) levels in UC. The results were expressed as mean \pm SEM of the sum of the obtained scores. \# $\mathrm{P}<0.05$ vs saline group, $* \mathrm{p}<0.05$ vs AA group. Statistical analysis was performed using the ANOVA variance test followed by the Newman-Keuls test.
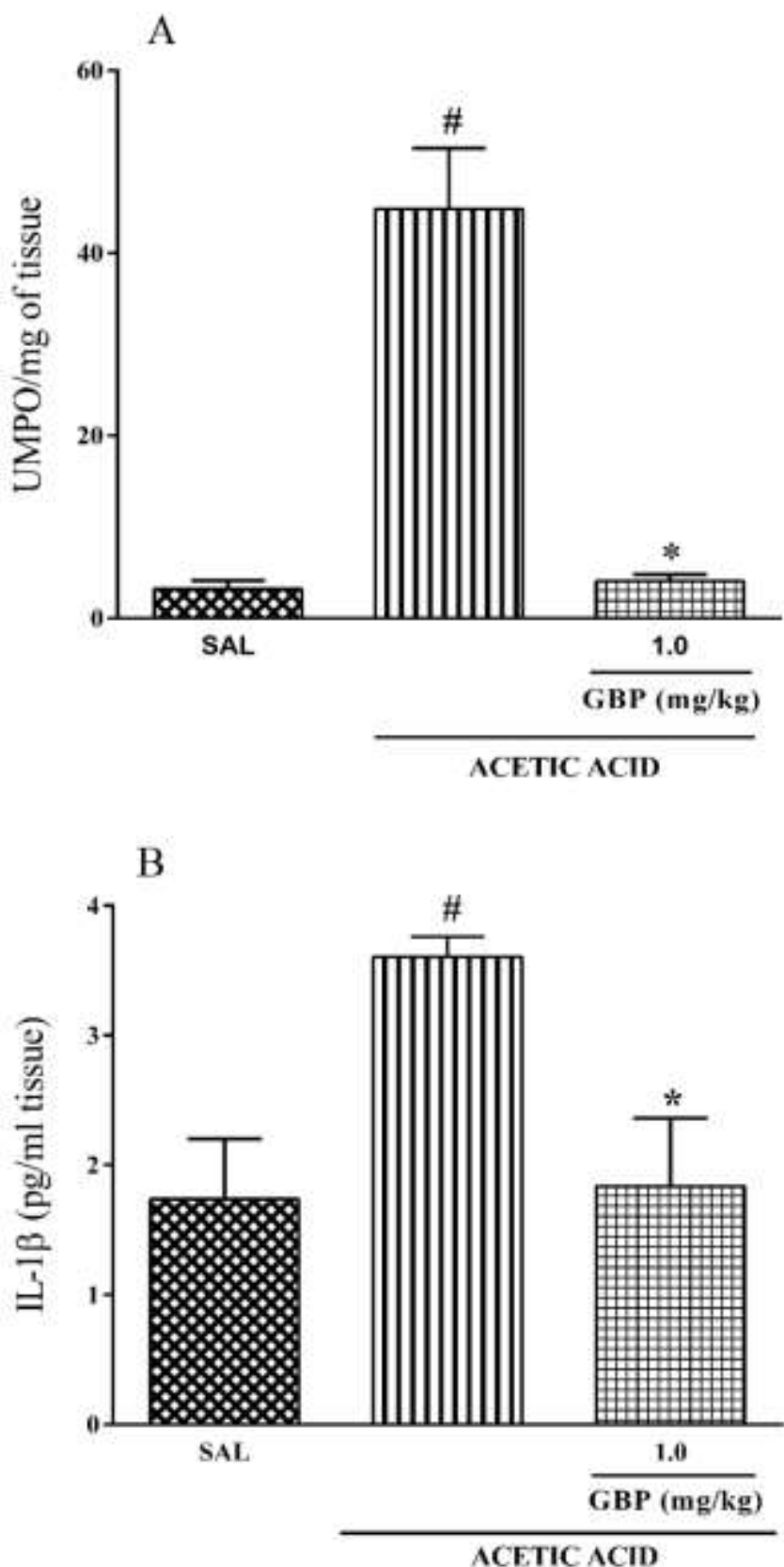

Source: Authors (2021).

Here it is important to note the effect of gabapentin in decreasing both MPO (A) activity and IL-1 $\beta$ (B) cytokine levels.

\subsection{GBP reduce MDA concentration in colon tissue}

Animals in the colitis group showed a significant increase (p <0.05) in MDA levels $(282.9 \pm 20.6 \mathrm{nmol} / \mathrm{mL})$ compared to the saline group $(80.71 \pm 11.12 \mathrm{nmol} / \mathrm{mL})$. GBP at doses of $1.0 \mathrm{mg} / \mathrm{kg}$ significantly reduced $(\mathrm{p}<0.05)$ the MDA level $(122.2 \pm 12.61 \mathrm{nmol} / \mathrm{mL})$ compared to colitis group (Figure $4 \mathrm{~A})$. 


\subsection{GBP restore or maintain GSH level}

The colitis group showed a significant increase $(\mathrm{p}<0.05)$ in the consumption of GSH levels $(24.19 \pm 3.96 \mu \mathrm{g} / \mathrm{mL})$ compared to the saline group $(118.5 \pm 7.74 \mu \mathrm{g} / \mathrm{mL})$. GBP at a dose of $1.0 \mathrm{mg} / \mathrm{kg}$ was able to significantly $(\mathrm{p}<0.05)$ restore GSH concentration $(62.49 \pm 8.15 \mu \mathrm{g} / \mathrm{mL})$ compared to the colitis group (Figure 4B).

Figure 4. GBP decreased MDA (A) levels and restored GSH (A) levels in the colon. The results were expressed as mean \pm SEM of the sum of the obtained scores. \# $\mathrm{P}<0.05$ vs saline group, $* \mathrm{p}<0.05$ vs AA group. Statistical analysis was performed using the ANOVA variance test followed by the Newman-Keuls test.

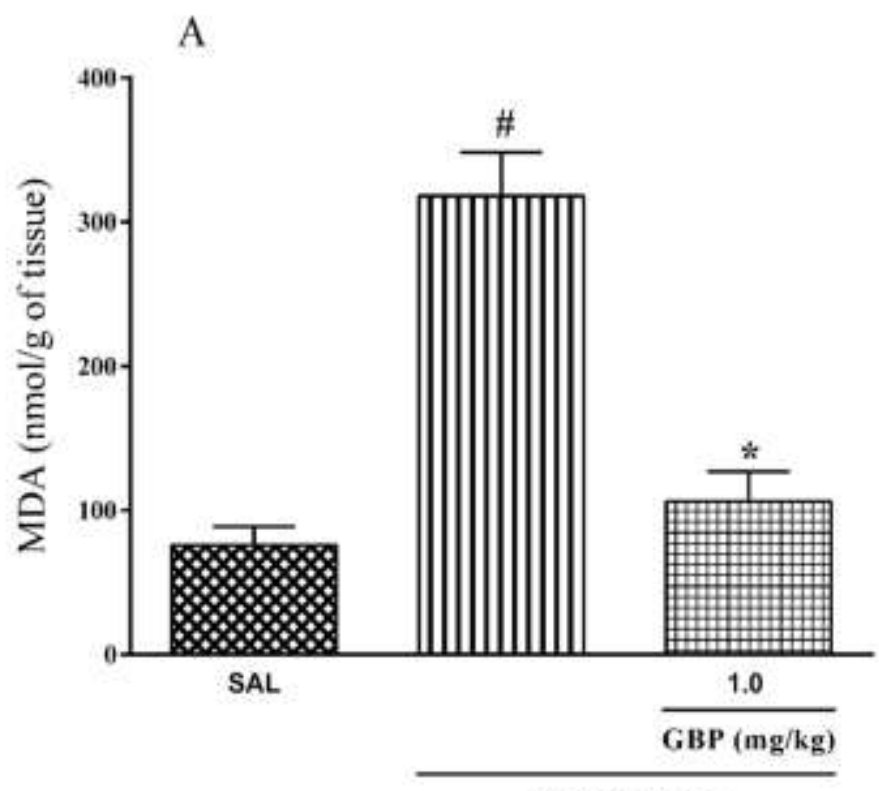

ACETIC ACID

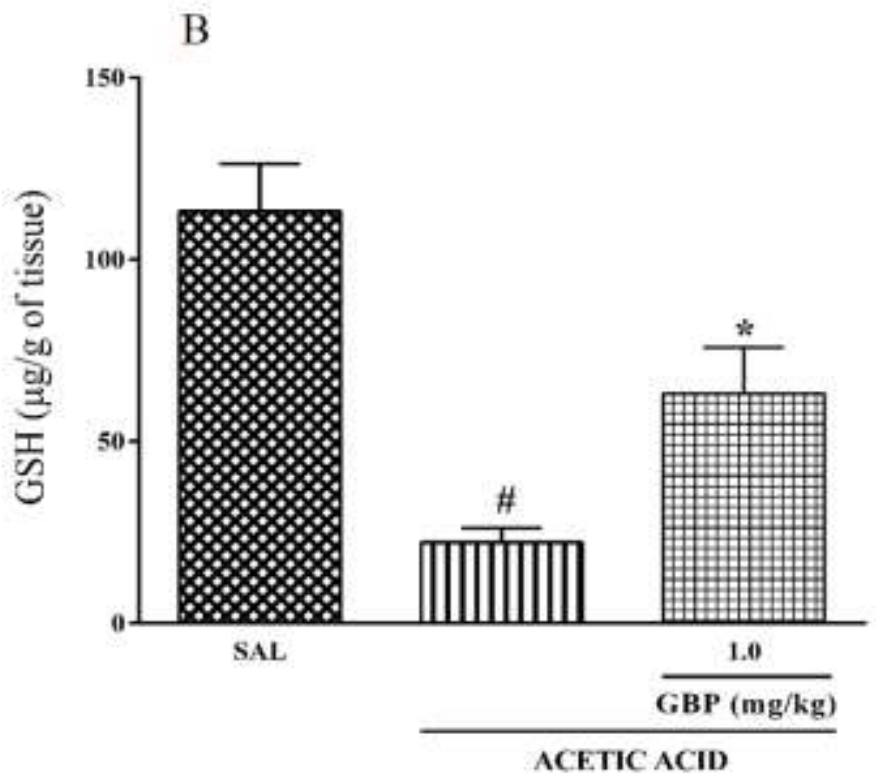

Source: Authors (2021).

In this figure, we draw attention to the effect of gabapentin in reducing the oxidative parameters caused by the administration of acetic acid in animals. In (A) we observe the decrease in MDA levels, whereas in (B) GBP promoted a maintenance of GSH levels. 


\subsection{ECs receptors do not participate in GBP effect on macroscopic lesion scores}

As seen in Figure 5 (A and B), the treatment with DMSO at 2\% (diluent of cannabinoids antagonists) in animals with colitis does not reverse the intestinal lesion macroscopic scores $(18.29 \pm 1.88)$ promoted by AA when compared this group with the saline $(0.42 \pm 0.20)$. On the order hand, the mice treated with GBP at dose of $1.0 \mathrm{mg} / \mathrm{kg}$ presented reduction of the macroscopic scores $(3.00 \pm 0.73)$ when compared with AA group. However, when such GBP-treated mice received intraperitoneally AM 251 and AM 630, they showed the following macroscopic scores: AM $251(2.20 \pm 0.48)$ and AM 630 $(3.16 \pm 0.65)$, also not having significant difference in macroscopic lesion scores when compared these groups with GBP group.

Figure 5. GBP reduced macroscopic score independent of endocannabinoid pathway. Animals were treated with GBP + AM251 (a) and GBP + AM 630 (b) or DMSO. The results were expressed as mean \pm SEM of the sum of the obtained scores. \# $\mathrm{P}<0.05$ vs saline group, $* \mathrm{p}<0.05$ vs AA group. Statistical analysis was performed using the ANOVA variance test followed by the Newman-Keuls test.
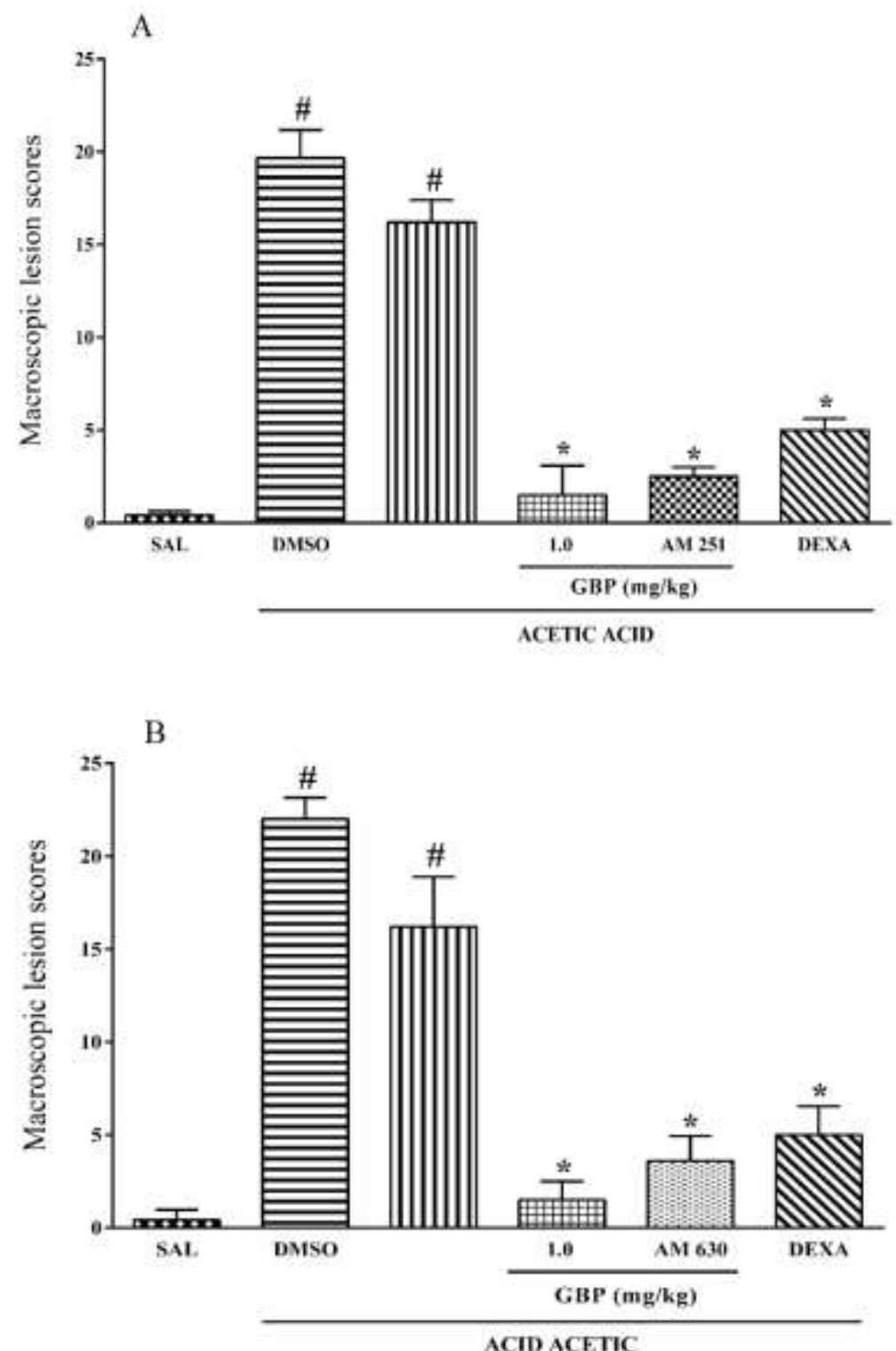

Source: Authors (2021). 
In this figure, it is important see that even in the presence of cannabinoid receptor antagonists, the effect of gabapentin continues when evaluating the macroscopic lesion parameter.

\subsection{ECs receptors do not participate in GBP effect on wet weight of the inflamed colon}

In Figure 6 (A and B) we can see that DMSO treatment at $2 \%$ in mice that were administered AA does not change the increase $(0.32 \pm 0.05 \mathrm{~g} / 5 \mathrm{~cm})$ of wet weight in mice with colitis. As expected, the treatments with GBP at the dose of $1.0 \mathrm{mg} / \mathrm{kg}$ promoted a significant decrease in the wet weight $(0.23 \pm 0.01 \mathrm{~g} / 5 \mathrm{~cm})$ compared to AA colitis group. However, when these GBP-treated mice received intraperitoneally AM 251 and AM 630, antagonist CB1 and CB2, respectively, showed the following wet weight: AM $251(0.21 \pm 0.01 \mathrm{~g} / 5 \mathrm{~cm})$ and $\mathrm{AM} 630(0.23 \pm 0.01 \mathrm{~g} / 5 \mathrm{~cm})$, what does not demonstrated a significant difference in wet weight when compared to GBP group.

Figure 6. GBP reduced wet weight regardless of endocannabinoid pathway. Animals were treated with GBP + AM 251 (a) and GBP + AM 630 (b) or DMSO. The results were expressed as mean \pm SEM of the sum of the obtained scores. \# P $<0.05$ vs saline group, * p <0.05 vs AA group. Statistical analysis was performed using the ANOVA variance test followed by the Newman-Keuls test.
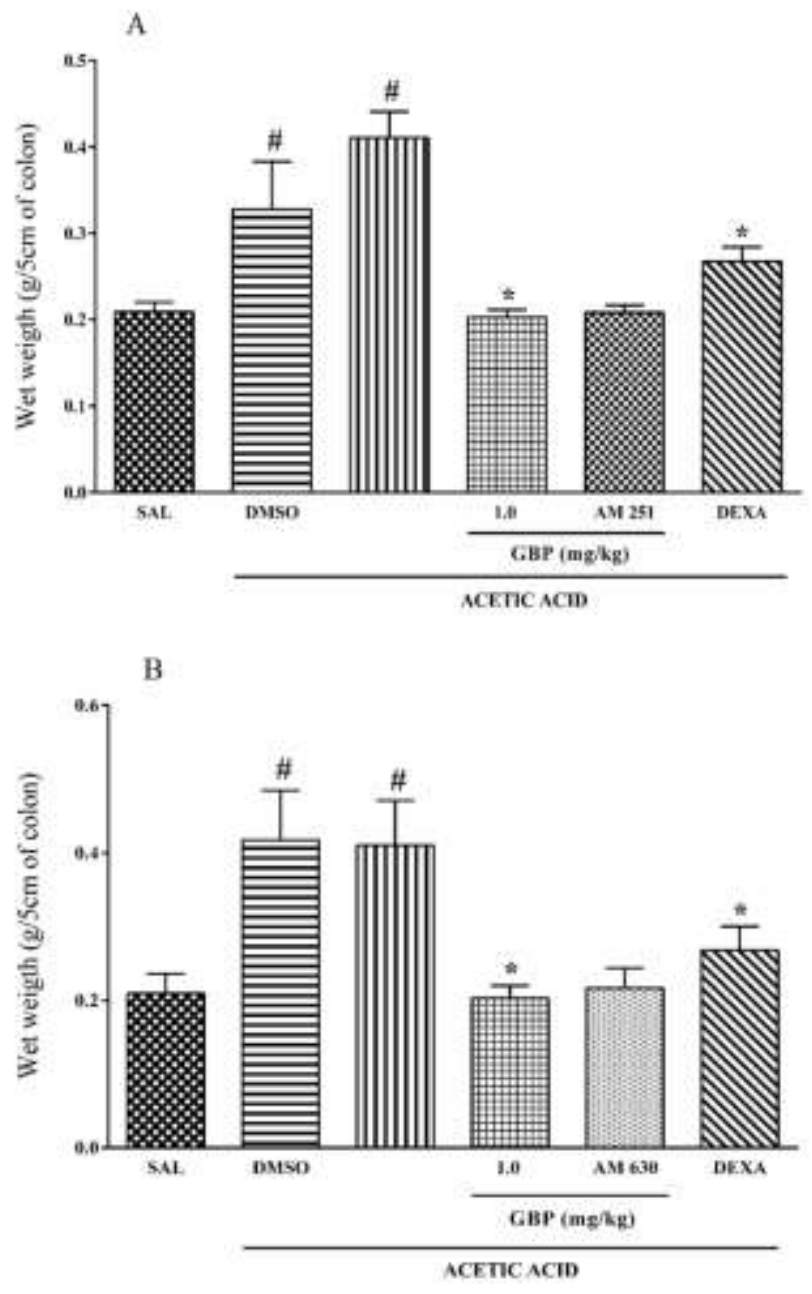

Source: Authors (2021). 
The figure above represents an inflammatory parameter which is the wet weight of $5 \mathrm{~cm}$ of the colon, here it is also important to note that even in the presence of cannabinoid receptor antagonists, the effect of gabapentin has continued, there is a decrease in wet weight of the total of animals with acetic acid-induced and GBP-treated colitis.

\subsection{ECs receptors do not participate in GBP effect on histopathological damages}

According to Table 2 and Figure 7 (A and B), AA administration and treatment with DMSO at 2\% promoted loss of mucosal architecture, intense cell infiltration, crypt abscess formation and goblet cell depletion, with microscopic scores totaling 11 (10-11). The groups treated with GBP (1.0 mg/kg i.p.) + AM 251 and GBP (1.0 mg/kg, i.p.) + AM 630, showed a significant decrease in the microscopic total parameters 3 (3-5) and 3 (3-6), respectively, according to Table 1 and Figure 7E, Figure 7F, respectively, what does not show a significant difference to AA + GBP group.

Table 2. Role of the endocannabinoid pathway on the GBP effect under the histopathological criteria of intestinal lesion caused by acetic acid-induced colitis in mice.

Histological lesion scores expressed as mean \pm error $(n=5-6)$. Non-parametric Kruskal-Wallis test followed by the Dunn test.

\# P $<0,05$ when compared to saline.

$* \mathrm{P}<0,05$ when compared to the control group (AA).

\begin{tabular}{lcccccc}
\hline Groups & $\begin{array}{c}\text { Loss of } \\
\text { architecture } \\
\text { infiltration }\end{array}$ & $\begin{array}{c}\text { Cellular } \\
\text { in-3) }\end{array}$ & $\begin{array}{c}\text { Muscle } \\
\text { thickening }\end{array}$ & $\begin{array}{c}\text { Crypt abscess } \\
\mathbf{( 0 - 3 )}\end{array}$ & $\begin{array}{c}\text { Goblet cell } \\
\text { depletion }\end{array}$ & $\begin{array}{c}\text { Total score } \\
\text { of damage }\end{array}$ \\
\hline Saline & $0(0-0)$ & $0(0-0)$ & $0(0-0)$ & $0(0-0)$ & $0(0-0)$ & $(\mathbf{0 - 1})$ \\
DMSO & $3(3-3) \#$ & $3(2-3) \#$ & $3(3-3) \#$ & $1(1-1) \#$ & $1(1-1) \#$ & $11(10-11) \#$ \\
AA & $3(3-3) \#$ & $3(2-3) \#$ & $3(2-3) \#$ & $1(1-1) \#$ & $1(1-1) \#$ & $11(10-11) \#$ \\
AA + GBP & $1(0-1)^{*}$ & $0(0-1)^{*}$ & $0(0-1)^{*}$ & $0(0-0)^{*}$ & $0(0-0)^{*}$ & $1(0-3)^{*}$ \\
GBP + AM251 & $1(1-2)$ & $1(1-1)$ & $1(1-1)$ & $0(0-1)$ & $0(0-1)$ & $3(3-5)$ \\
GBP + AM630 & $1(1-2)$ & $1(1-1)$ & $1(1-2)$ & $0(0-1)$ & $0(0-1)$ & $3(3-6)$ \\
AA + DEXA & $1(0-1)^{*}$ & $1(0-1)^{*}$ & $1(0-1)^{*}$ & $0(0-0)^{*}$ & $0(0-0)^{*}$ & $3(0-3)^{*}$
\end{tabular}

Source: Authors (2021).

In this table, it is important to note the decrease in histopathological scores of lesions caused by the action of gabapentin. Furthermore, when in the presence of cannabinoid receptor antagonists, the effect of gabapentin observed in the histopathological parameters was not abolished. 
Figure 7. Microphotography (200x, $50 \mu \mathrm{m}$ scale) of GBP effect independent of endocannabinoid pathwayon intestinal damage. Saline solution (A); AA (B); GBP (C); AA + DMSO (D); AA + GBP + AM 251 (E); AA + GBP + AM 630 (F). AA + Dexamethasone $(\mathrm{G})$. Red arrows: architecture of the mucosa (villi and crypts); yellow arrows: cellular infiltration; black arrows: muscular thickening.
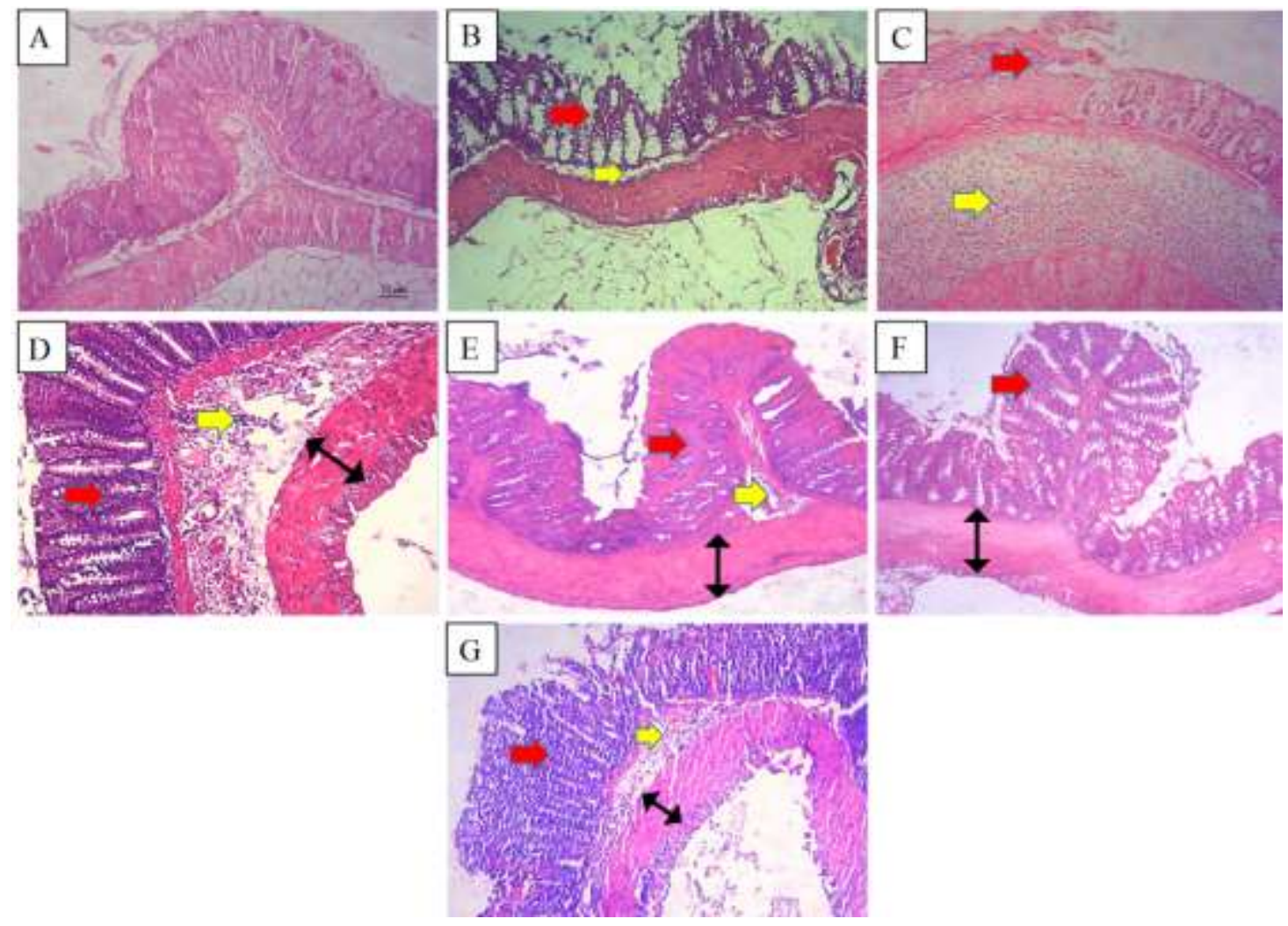

Source: Authors (2021).

In the figure above, it is important to note that the lesion caused by acetic acid resulted in histological tissue destruction of the animals colon, see (B). It is important to note in (C) that the treatment of these animals with gabapentin promoted an improvement in the histopathological condition of the colon of these animals. When these animals were administered cannabinoid receptor antagonists, there was no reversal of the effect of gabapentin, note in $(E)$ and $(F)$.

\subsection{ECs receptors do not participate in GBP effect on GSH, MDA, MPO and IL-1ß levels}

As showed in Figures 8, 9, 10, 11 (A and B), the AA + DMSO group presented the following results: MDA (389.2 \pm $34.14 .89 \mathrm{nmol} / \mathrm{g})$, MPO (32.86 $\pm 4.03 \mathrm{UMPO} / \mathrm{mg}), \mathrm{IL}-1 \beta(3.73 \pm 0.19 \mathrm{pg} / \mathrm{mL})$ and GSH $(41.52 \pm 6.60 \mu \mathrm{g} / \mathrm{g})$. The groups treated with GBP (1.0 mg/kg i.p.) plus AM 251 or GBP (1.0 mg/kg, i.p.) plus AM 630, didn’t showed significant differences $(\mathrm{p}<0.05)$ on the inflammatory markers when compare these groups $(\mathrm{GBP}+\mathrm{AM} 251: \mathrm{MDA}=150.2 \pm 15.88 \mathrm{nmol} / \mathrm{g}$ tissue; $\mathrm{GSH}=71.89 \pm 9.259 \mu \mathrm{g} / \mathrm{g} ; \mathrm{MPO}=10.56 \pm 2.33 \mathrm{UMPO} / \mathrm{mg}$ of tissue and $\mathrm{IL}-1 \beta=2.73 \pm 0.26 \mathrm{pg} / \mathrm{ml} / \mathrm{GBP}+\mathrm{AM} 630: \mathrm{MDA}=$ 106.8.2 $\pm 18.58 \mathrm{nmol} / \mathrm{g}$ tissue; $\mathrm{GSH}=71.39 \pm 8.94 \mu \mathrm{g} / \mathrm{g} ; \mathrm{MPO}=7.33 \pm 1.73 \mathrm{UMPO} / \mathrm{mg}$ of tissue and $\mathrm{IL}-1 \beta=2.34 \pm 0.40$ $\mathrm{pg} / \mathrm{ml}$ ) with GBP group. 
Figure 8. GBP decreased colon MPO levels independent of the endocannabinoid pathway. Endocannabinoid block with AM 251 (A) and AM 630 (B). The results were expressed as mean \pm SEM of the sum of the obtained scores. \# P <0.05 vs saline group, $*$ p $<0.05$ vs AA group. Statistical analysis was performed using the ANOVA variance test followed by the NewmanKeuls test.

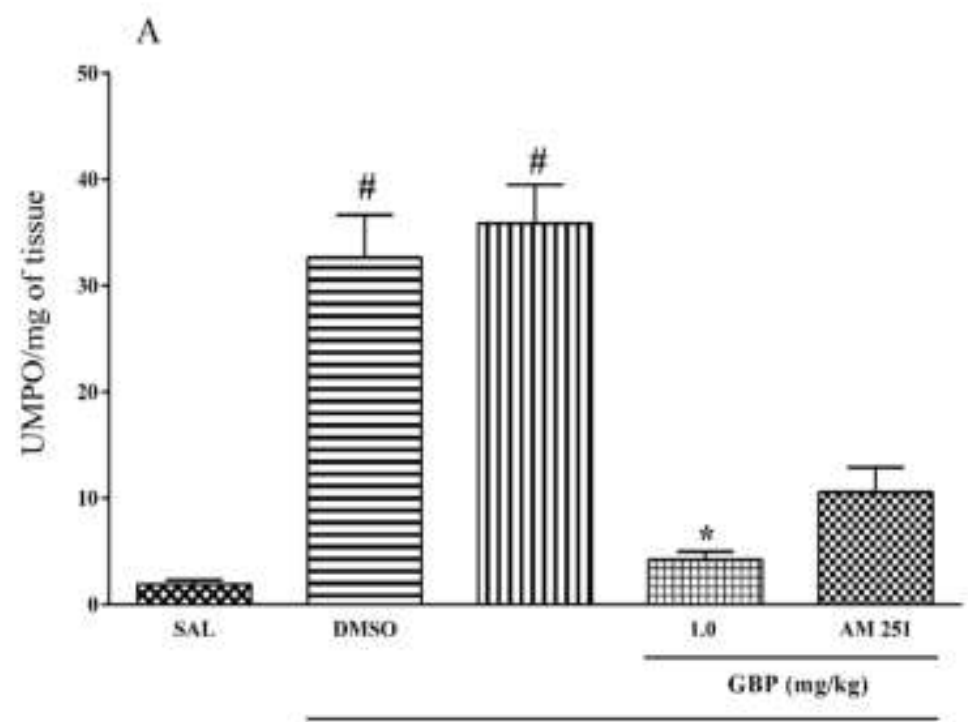

ACETIC ACID

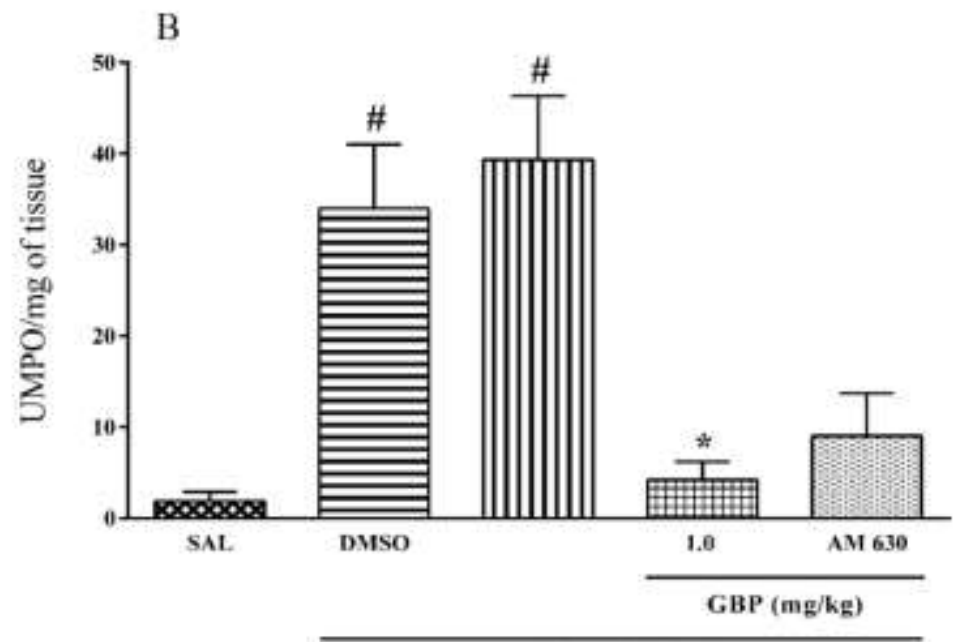

ACETIC ACID

Source: Authors (2021).

In this figure, it is important to note that even in the presence of cannabinoid receptor antagonists; the effect of gabapentin on MPO activity has be maintained. 
Figure 9. GBP decreased MDA levels in the colon independent of the endocannabinoid pathway. Endocannabinoid block with AM 251 (A) and AM 630 (B). The results were expressed as mean \pm SEM of the sum of the obtained scores. \# P <0.05 vs saline group, * p <0.05 vs AA group. Statistical analysis was performed using the ANOVA variance test followed by the Newman-Keuls test.

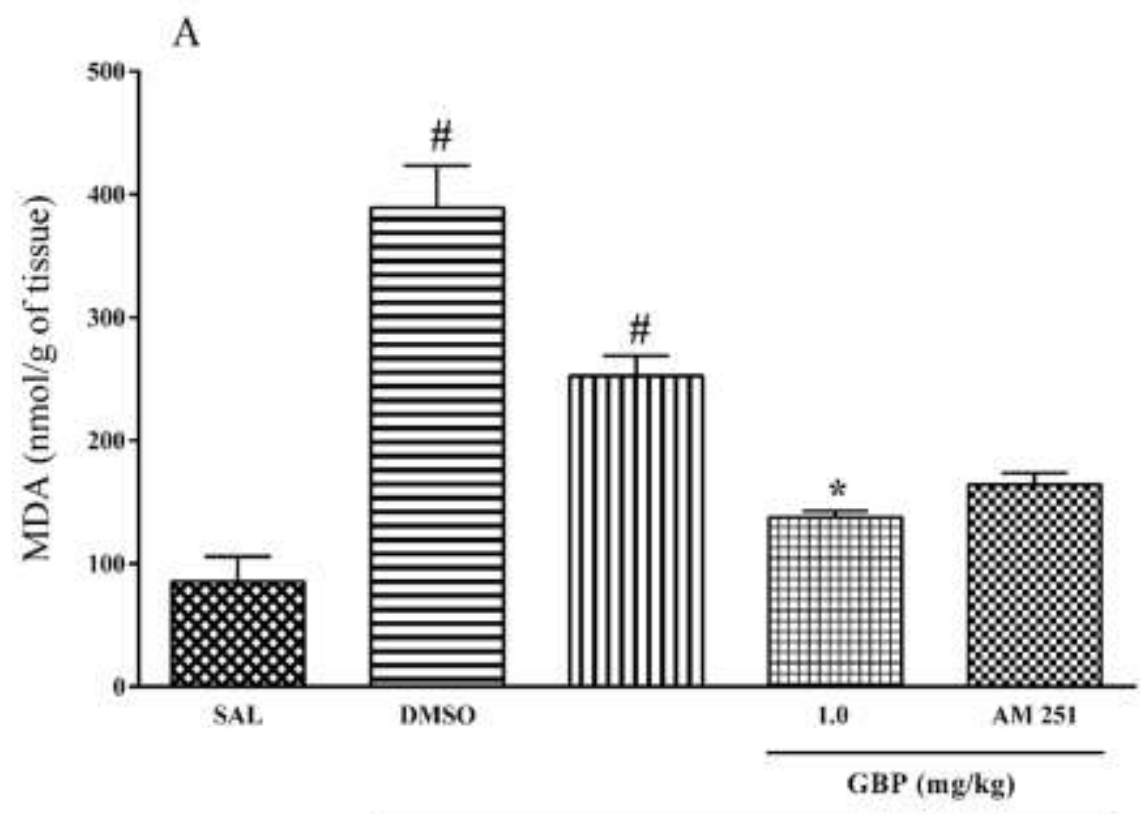

ACETIC ACID

B

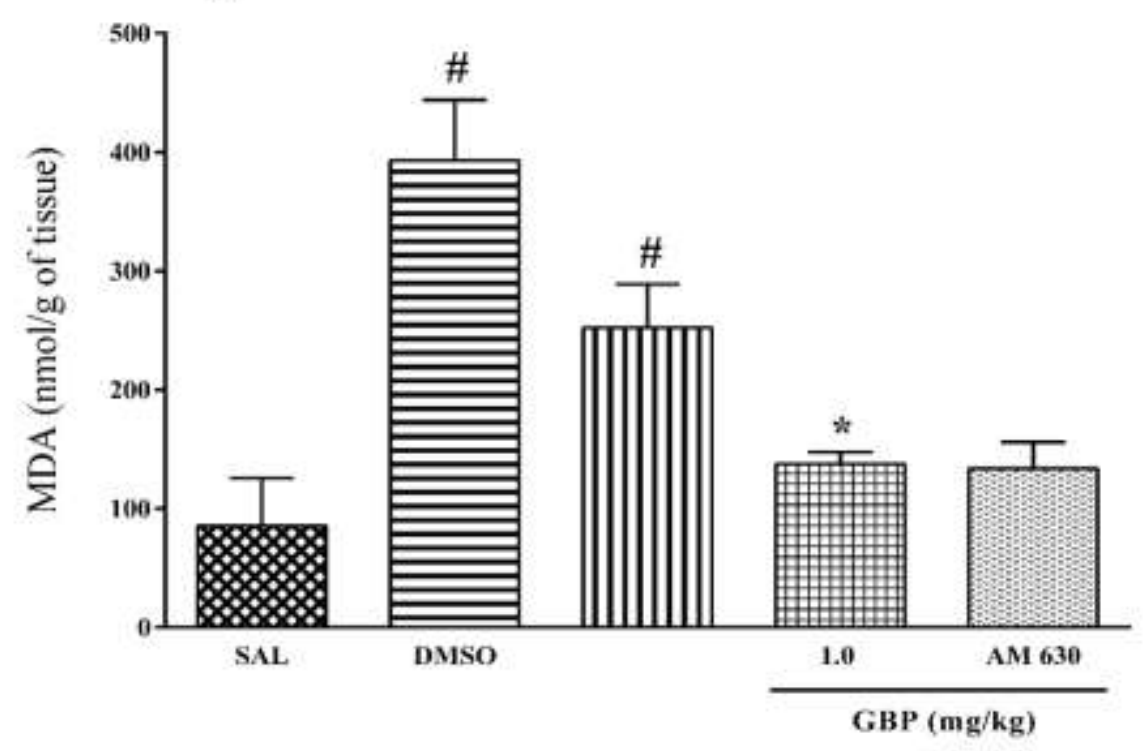

ACETIC ACTD

Source: Authors (2021).

In the figure above, it is important to note that the effect of gabapentin on MDA concentration has be maintained even in the presence of cannabinoid receptor antagonists. 
Figure 10. The GBP restored GSH levels in the colon independent of the endocannabinoid pathway. Endocannabinoid block with AM 251 (A) and AM 630 (B). The results were expressed as mean \pm SEM of the sum of the obtained scores. \# P $<0.05$ vs saline group, * p <0.05 vs AA group. Statistical analysis was performed using the ANOVA variance test followed by the Newman-Keuls test.

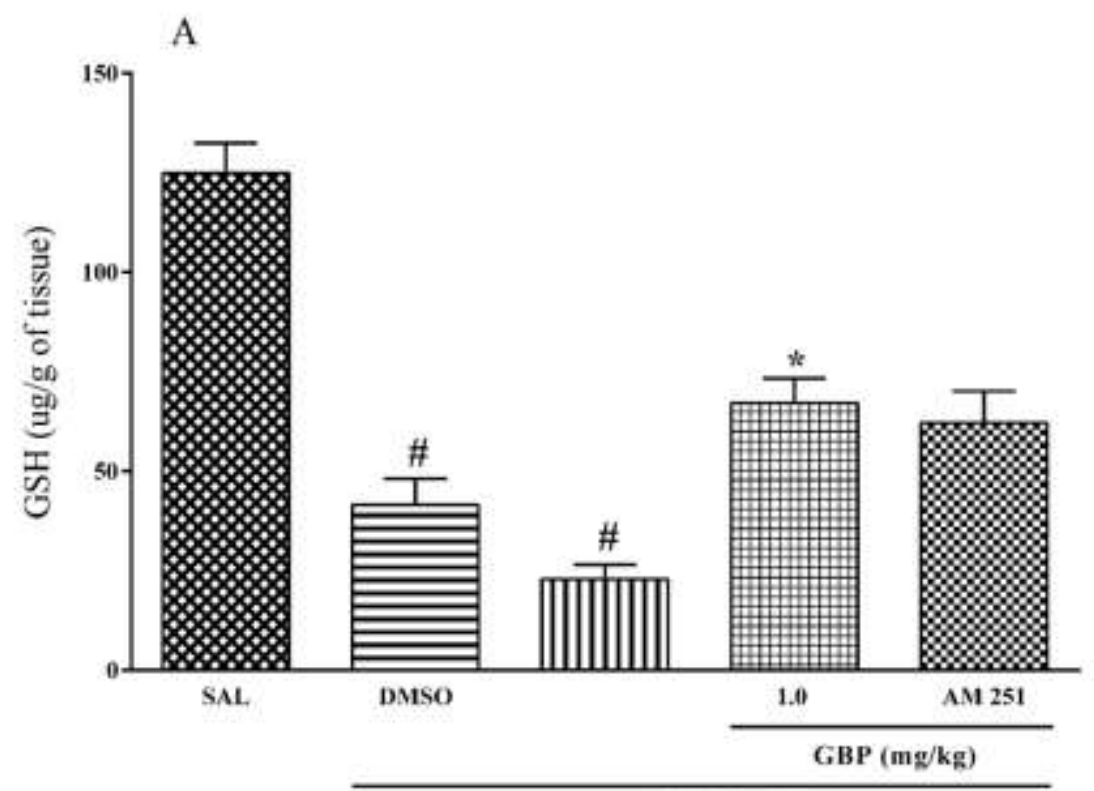

ACETIC ACID

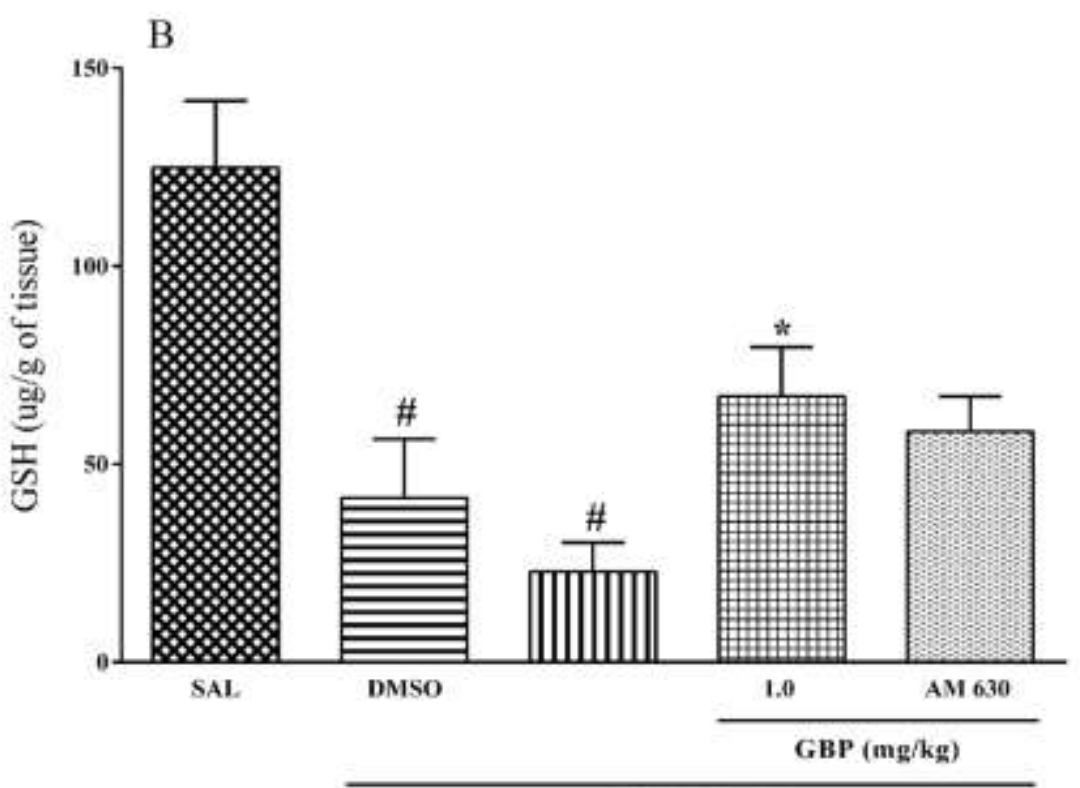

ACETIC ACID

Source: Authors (2021).

Here it is important to note that the ability to maintain GSH levels of the GBP was maintained even in the presence of cannabinoid receptor antagonists. 
Figure 11. GBP decreased IL1- $\beta$ levels in the colon independent of the endocannabinoid pathway. Endocannabinoid block with AM 251 (A) and AM 630 (B). The results were expressed as mean \pm SEM of the sum of the obtained scores. \# P <0.05 vs saline group, * p <0.05 vs AA group. Statistical analysis was performed using the ANOVA variance test followed by the Newman-Keuls test.

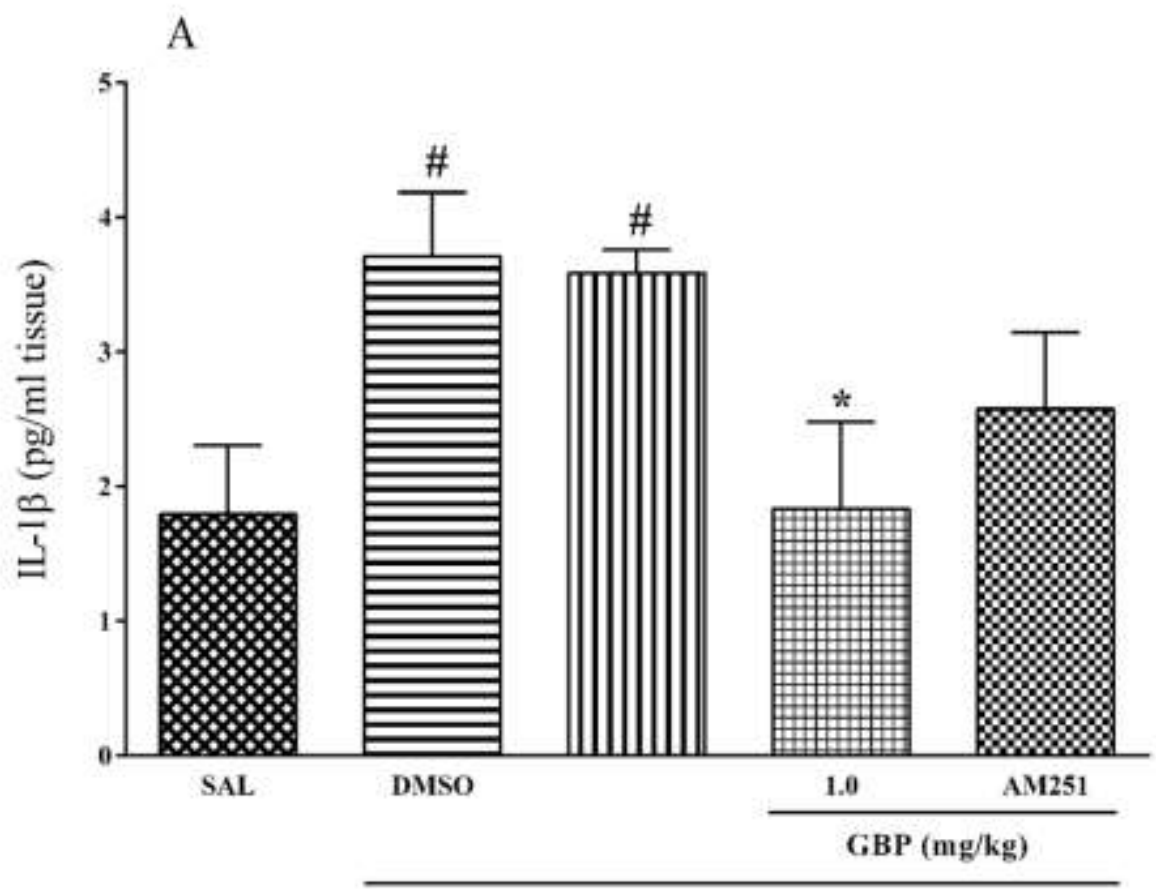

\section{ACETIC ACID}

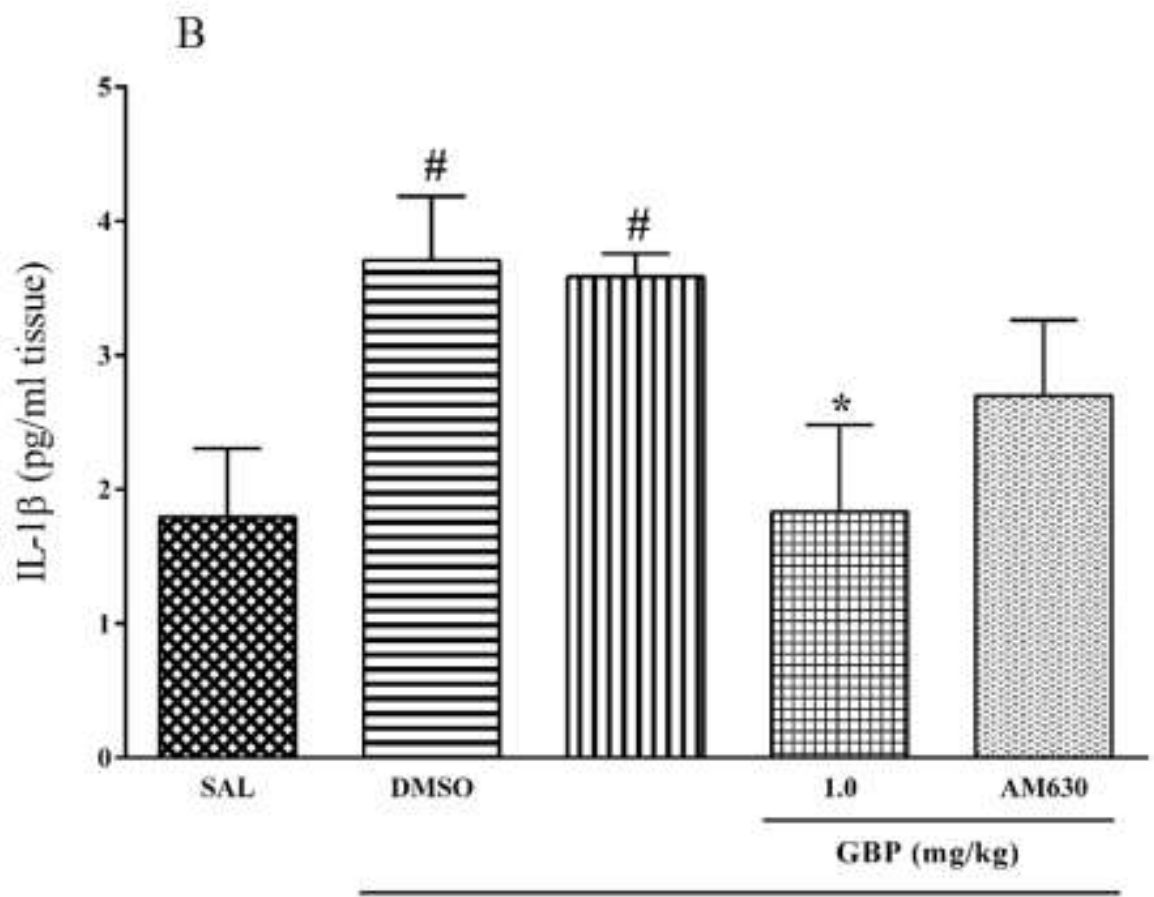

ACETICACID

Source: Authors (2021). 
The figure above draws attention to the effect of gabapentin on IL-1B levels, where we observed that the effect of GBP in reducing cytokine levels have been maintained even in the presence of cannabinoid receptor antagonists.

\section{Discussion}

Ulcerative colitis (UC) is a chronic inflammatory disorder defined by mucosal inflammation in a continuous pattern; this disease has been characterized by presenting itself in a chronic disease with no known preventative or curative interventions, therapy is most often lifelong. The natural course of UC includes periods of remission interspersed with periods of acute exacerbations. The goal of treatment is to achieve disease remission and prevent disease-related complications such as infection, surgery, and neoplasia, as well as preserve patient's quality of life (Kayal \& Shah, 2019). Clinical therapies for UC include anti-inflammatory steroids, NSAIDs and TNF- $\alpha$ inhibitors; these are solely used for disease control, and do not represent cures. In addition, they can result in significant side effects and severe recurrence spikes. Therefore, new strategies against IBD are necessary (de Brito et al, 2020).

Recently we showed that gabapentin has a significant anti-inflammatory action in models of inflammatory bowel diseases (de Brito et al, 2020); in this same research, we show that this effect attributed to GBP is due in part to its interrelation with the PPAR-gamma receptor. Even though we know about this GBP mechanism of action, we need to further unravel the alternative pathways by which GBP may be acting during its intestinal anti-inflammatory effect. Therefore, we decided to evaluate in this work the participation of endocannabinoid receptors in this intestinal anti-inflammatory effect of GBP.

This work evidenced GBP action against the inflammation and derivate of oxidative stress of the inflamed mucosa on the AA-induced colitis. GBP treatment in colitis mice restored pro-inflammatory parameters, ameliorates histopathological profile with significant $(\mathrm{p}<0.05)$ decrease of the biochemical markers as MPO, MDA and GSH, besides this, reduced IL-1 $\beta$ levels. However, there is no participation CB1 and CB2 cannabinoids receptors in this action.

The intestinal damage induced by AA in mice is a process with similar feature ulcerative colitis in humans (Rani, Smulian, Greaves, Hogan \& Herbert, 2011) with diffuse mucosal inflammation, ulceration, goblet cell depletion, intense neutrophil infiltration, and macrophage activation, production of inflammatory cytokines, also generating disrupting epithelial integrity and causing colon injury. Knowing this pathological condition of the ulcerative colitis induced by AA (Grisham, Yamada, Specian \& Grisham, 1992; Verri et al, 2010), we proposed to study GBP effect in experimental disease using classical assays of the inflammatory process, such as macroscopic and microscopic scores of lesion, colonic wet weight, MDA, GSH, MPO and measurement of pro-inflammatory cytokine interleukin 1 beta (IL-1 $\beta$ ) on inflamed mucosa. Besides this, we evaluated also the role of cannabinoids receptors (CB1 and CB2) in GBP action.

Firstly, we studied the action of the GBP under the disruption of mucosa architecture. Our results demonstrated that GBP significantly decreases macroscopic colon lesion, microscopic tissue damage scores and colonic wet weight at the dose of $1.0 \mathrm{mg} / \mathrm{kg}$ (the dose was used in all of the other assays), but the treatment with cannabinoids antagonist CB1 and CB2 receptors (AM251 and AM630, respectively) did not reverse the action of GBP.

Macroscopic analysis and colon weight assay are considered as important protocols to measure colon tissue edema, ulcerations, intestinal wall thickening and intensity of inflammation (Lee et al, 2009; Witaicenis et al, 2014). The improvement of microscopic scores of lesion observed through the treatment with GBP is probably due to the reduction of the mucosa inflammation in mice, and that strong effect seems to be independent of cannabinoid pathway.

Edema and increased colon weight also occurs due to neutrophil activity, MPO activity is associated with neutrophil infiltration and has been used as an important marker of tissue damage arising from inflammatory cellular infiltration 
(Halliwell, 1996; Tewari-Singh et al, 2009). In the evaluation of the action of the GBP under the MPO activity on colitis by AA, we observed that this drug $(1.0 \mathrm{mg} / \mathrm{kg})$ was able to reduce the MPO activity on colonic mucosa of the animals with colitis. However, this effect does not change with the administration of cannabinoid antagonists (AM 251 and AM 630). Thus, we can say that GBP decrease the intestinal damage by modulating the neutrophil action in inflamed colon, and that event occurs without cannabinoid participation.

The neutrophils have a crucial role during colon damage induced by chemical agents is characterized by the production of several inflammatory components and products, such as release of pro-inflammatory cytokines and free radicals. Cytokines as IL-1 $\beta$ are increased in inflamed tissue and are an important tool to recruit polymorphonuclear cells (neutrophils) into the inflammatory site (Katz, Itoh \& Fiocchi, 1999). Our data showed that the treatment with GBP reduced the level of IL$1 \beta$ in animals with colitis, but the treatment with AM 251 and AM 630 was not able to modify the GBP action. Thus, we can infer that this anticonvulsant agent reduces colonic inflammation by reducing neutrophil infiltration dependent on cytokine production, and that action is not modulated by cannabinoid receptors.

A critical role of the pathogenesis during inflammatory bowel diseases is the formation and release of free radicals promoting lipid peroxidation. These events are associated with neutrophil infiltration within the inflamed colon mucosa with the overproduction of reactive oxygen species that disrupt the balance of the antioxidant protective mechanisms, which perpetuates inflammation of the colon (Martin, Villegas, La Casa \& La Lastra, 2004). Under the influence of free radicals on the pathogenesis of the colitis, we decided to perform GSH and MDA assays that are the two oxidative stress markers. Our results showed that GBP decreased the MDA concentration on inflamed mucosa in mice with colitis and was able to restore the GSH cellular stock. This GBP effect was not altered after AM 251 and AM 630 administration.

MDA is derived from the lipid peroxidation and its production is a consequence of the colonic oxidative insult. GSH is an endogenous antioxidant that protects the tissues against oxidative damage through the maintenance of the sulfhydryl radicals protecting the proteins against oxidation (Amirshahrokhi, Bohlooli \& Chinifroush, 2011). According to our findings, we can infer that GBP act in colonic inflammation reducing MDA levels and restore the GSH cellular concentration, inhibiting the maintenance of the production of the free radicals that are responsible for the aggravation of the colonic inflammatory process. The cannabinoid pathway does not have any participation in this anti-inflammatory action.

\section{Conclusion}

Our results demonstrate that GBP possess a significant anti-inflammatory intestinal effect due to its having diminished several colonic inflammatory parameters. This effect seems to happen due to a modulation of inflammatory events and mediators such as oxidative stress, neutrophil migration and mainly pro-inflammatory cytokines. When we verified the participation of CB1 and CB2 receptors in the anti-inflammatory effect of gabapentin; we observe that the endocannabinoid receptor antagonist $\mathrm{AM} 251$ and $\mathrm{AM} 630$ for $\mathrm{CB} 1$ and $\mathrm{CB} 2$ respectively, did not occur no change in the intestinal antiinflammatory effect of gabapentin; this shows us that the anti-inflammatory effect of gabapentin seems to happen independently of CB1 and CB2 receptors. The results presented in this work make it clear that the intestinal anti-inflammatory effect of GBP does not occur through cannabinoid receptors, however we intend to investigate in the future what other possible pharmacological pathways may be participating during the effect promoted by GBP.

\section{Acknowledgements}

The authors are grateful to the Brazilian Agency for Scientific and Technological Development-CNPq (Brazil) and Federal University of Piauí - UFPI (Brazil), by financial and structural support. 


\section{References}

Abdel-Salam, O. M. E. \& Sleem, A. A. (2009). Study of the analgesic, anti-inflammatory, and gastric effects of gabapentin. Drug. Discov. Therapeutic, 3(1), $18-26$.

Amirshahrokhi, K. Bohlooli, S. \& Chinifroush, M. M. (2011). The effect of methylsulfonylmethane on the experimental colitis in the rat. Toxicol. Appl. Pharmacol, 253(3), 197-202.

Appleyard, C. B. \& Wallace, J. L. (1995). Reactivation of hapten-induced colitis and its prevention by anti- inflammatory drugs. Am. J. Physiol, 269(1), G119-25.

Arendt-Nielsen, L. Frøkjær, J. B. Staahl, C. Graven-Nielsen, T. Huggins, J. P. Smart, T. S. \& Drewes, A. M. (2007). Effects of Gabapentin on Experimental Somatic Pain and Temporal Summation. Regional Anesthesia and Pain Medicine, 32(5), 382-388.

Brito, T. V. Barros, F. C. N. Silva, R. O. Dias Júnior, G. J. Júnior, J. S. Franco, C. Á. X. Soares, P. M. G. Chaves, L. S. Abreu, C. M. W. S. de Paula, R. C. M. Souza, M. H. L. P. Freitas, A. L. P, \& Barbosa, A. L. R. (2016). Sulfated polysaccharide from the marine algae Hypnea musciformis inhibits TNBS-induced intestinal damage in rats. Carbohydrate Polymers, 151, 957-964.

Brito, T. V. Júnior, G. J. D. da Cruz Júnior, J. S. Silva, R. O. da Silva Monteiro, C. E. Franco, A. X. Vasconcelos, D. F. P. de Oliveira, J. S. Costa, D. V. S. Carneiro, T. B. Duarte, A. S. G. Souza, M. H. L. P Soares, P. M. G. \& Barbosa, A. L. R. (2020) Gabapentin attenuates intestinal inflammation: Role of PPARgamma receptor. Eur J Pharmacol, 873 (2020), 172974.

Dias, J. M. de Brito, T. V. Magalhães, D. A. Santos, P. W. S. Batista, J. A. Nascimento Dias, E. G. Fernandes, H. B. Damasceno, S. R. B. Silva, R. O. Aragão, K. S. Souza, M. H. L. P. Medeiros, J. V. R. \& Barbosa, A. L. R. (2014). Gabapentin, a synthetic analogue of gamma aminobutyric acid, reverses systemic acute inflammation and oxidative stress in mice. Inflammation, 37(5), 1826-1836.

Grisham, M. B. Yamada, T. Specian, R. D. \& Grisham, M. B. (1992). A comparative analysis of two models of colitis in rats. Gastroenterology, 102(5), 1524-34.

Guazelli, C. F. S. Fattori, V. Colombo, B. B. \& Georgetti, S, R. (2013). Quercetin-Loaded Microcapsules Ameliorate Experimental Colitis in Mice by Antiinflammatory and Antioxidant Mechanisms. Journal of Nataral Products, 76(2), 200-208.

Halliwell, B. (1996). Antioxidants in human health and disease. Ann. Rev. Nutr, 16, 33-50.

Hoppa, M. B. Lana, B. Margas, W. Dolphin, A. C. \& Ryan, T. A. (2012). $\alpha 2 \delta$ expression sets presynaptic calcium channel abundance and release probability. Nature, 486(7401), 122-125.

Ihenetu, K. Molleman, A. Parsons, M. \& Whelan, C. (2003). Pharmacological characterisation of cannabinoid receptors inhibiting interleukin 2 release from human peripheral blood mononuclear cells. Eur. J. Pharmacol, 464(2-3), 207-215.

Izzo, A. A. \& Camilleri, M. (2009). Cannabinoids in intestinal inflammation and cancer. Pharmacol Res, 60(2), 117-25.

Katz, J. A. Itoh, J. \& Fiocchi, C. (1999) Pathogenesis of inflammatory bowel disease. Curr. Opin. Gastroenterol, 15(4), $291-297$.

Kayal, M. \& Shah, S. (2019). Ulcerative Colitis: Current and Emerging Treatment Strategies. J Clin Med, 9(1), 94.

Khor, B. Gardet, A. \& Xavier, R. J. 2011. Genetics and pathogenesis of inflammatory bowel disease. Nature, 474 (7351), $307-317$.

Klein, T. W. Newton, C. Larsen, K. Lu, L. Perkins, I. \& Nong, L. (2003). The cannabinoid system and immune modulation. J. Leukoc. Biol, 74(4), 486-96.

Lee, J. Y. Kang, H. S. Park, B. E. Moon, H. J. Sim, S. S. Kim, C. J. J. (2009). Inhibitory effects of Geijigajakyak-Tang on trinitrobenzene sulfonic acidinduced colitis. Ethnopharmacol, 126(2), 244-251.

Lynch, W. D. \& Hsu, R. (2020). Ulcerative Colitis. StatPearls.

Marquéz, L, Suárez, J. Iglesias, M. Bermudez-Silva, F. J. De Fonseca, F. R. \& Andreu, M. (2009). Ulcerative Colitis Induces Changes on the Expression of the Endocannabinoid System in the Human Colonic Tissue. Plos One, 4(9), e6893.

Martin, A. R. Villegas, I. La Casa, C. \& La Lastra, C. A. (2004). Resveratrol, a polyphenol found in grapes, suppresses oxidative damage and stimulates apoptosis during early colonic inflammation in rats. Biochem Pharmacol, 67(7), 1399-410.

Massa, F. Marsicano, G. Hermann, H. Cannich, A. Monory, K. Cravatt, B. F. Ferri, G. L. Sibaev, A. Storr, M. \& Lutz, B. (2004). The end ogenous cannabinoid system protects against colonic inflammation. J Clin Investig, 113(8), 1202-1209.

Mihara, M. \& Uchiyama, M. (1978). Determination of malondialdehyde precursor in tissue by thiobarbituric acid test. Anal Biochem, 86(1), 271-278.

Morris, G. P. Beck, P. L. Herridge, M. S. Depew, W. T. Szewczuk, M. R. \& Wallace, J. L. (1989). Hapten-induced model of chronic inflammation and ulceration in the rat colon. Gastroenterology, 96(3), 795-803.

O’Sullivan, S. E. (2016). An update on PPAR activation by cannabinoids. Br J Pharmacol, 173(12), 1899-910.

Podolsky, D. K. (1991). Inflammatory bowel disease (Review article). N Engl J Medicine, 325(14), 1008-1016.

Pereira, A. S. Shitsuka, D. M. Parreira, F. J. \& Shitsuka R. (2018). METODOLOGIA DA PESQUISA CIENTÍFICA. Santa Maria, RS : UFSM, NTE, 
Research, Society and Development, v. 10, n. 7, e38510716693, 2021

(CC BY 4.0) | ISSN 2525-3409 | DOI: http://dx.doi.org/10.33448/rsd-v10i7.16693

Rani, R. Smulian, A. G. Greaves, D. R. Hogan, S. P. \& Herbert, D. R. (2011). TGF-beta limits IL-33 production and promotes the resolution of colitis through regulation of macrophage function. Eur J Immunol, 41(7), 2000-2009.

Robbins, C. (2012). Fundamentos de Patologia. Elsevier.

Rodríguez, M. M. Sánchez, B. P. Merlos, M. \& Garzón, N. J. (2016). Endocannabinoid control of glutamate NMDA receptors: the therapeutic potential and consequences of dysfunction. Oncotarget, 7(34), 55840-55862.

Sedlak, J. \& Lindsay, R. H. (1968). Estimation of total, proteinbound, and nonprotein sulfhydryl groups in tissue with Ellman's reagent. Anal Biochem, 25(1), 192-205.

Silva, V. G. Silva, R. O. Damasceno SR, Carvalho, N. S. Prudêncio, R. S. Aragão, K. S. Guimarães, M. A. Campos, S. A. Véras, L. M. C. Godejohann, M. Leite, J. R. S. A. Barbosa, A. L. R. \& Medeiros J. V. R. (2013). Anti-inflammatory and antinociceptive activity of epiisopiloturine, an imidazole alkaloid isolated from Pilocarpus microphyllus. Journal of natural products, 76(6), 1071-1077.

Storr, M. A. Keenan, C. M. Zhang, H. Patel, K. D. Makriyannis, A. \& Sharkey, K. A. (2009). Activation of the cannabinoid 2 receptor (CB2) protects against experimental colitis. Inflammatory Bowel Diseases, 15(11), 1678-1685.

Tavares-Murta, B. M. de Resende, A. D. Cunha, F. Q. \& Murta, E. F. C. (2008). Local profile of cytokines and nitric oxide in patients with bacterial vaginosis and cervical intraepithelial neoplasia. Eur J Obstet Gynecol Repro Biol, 138(1), 93-99.

Taylor, C. P. \& Harris, E. W. (2020). Analgesia with gabapentin and pregabalin may involve N-methyl-D-aspartate receptors, neurexins, and thrombospondins. J Pharmacol Exp Ther, 374(1), 161-74.

Tewari-Singh, N. Rana, S. Gu, M. Pal, A. Orlicky, D. J. White, C. W. \& Agarwal, R. (2009). Inflammatory Biomarkers of Sulfur Mustard Analog 2Chloroethyl Ethyl Sulfide-Induced Skin Injury in SKH-1 Hairless Mice. Toxicological Sciences, 108(1), 194-206.

Verri, W. A. Jr. Souto, F. O. Vieira, S. M. Almeida, S. C. L. Fukada, S. Y. Xu, D. Alves-Filho, J. C. Cunha, T. M. Guerrero, A. T. G. Mattos-Guimaraes, R. B. Oliveira, F. R. Teixeira, M. M. Silva, J. S. McInnes, I. B. Ferreira, S. H. Louzada-Junior, P. Liew, F. Y. Cunha, F. Q. (2010). IL-33 induces neutrophil migration in rheumatoid arthritis and is a target of anti-TNF therapy. Ann. Rheum. Dis, 69(9), 1697-1703.

Witaicenis, A. Seito, L. N. da Silveir, C. A. de Almeida Jr, L. D. Luchini, A. C. Rodrigues-Orsi, P. Cestari, S. H. \& Di Stasi L. C. (2014). Antioxidant and intestinal anti-inflammatory effects of plantderived coumarin derivatives. Phytomedicine, 21(3), 240-246.

Sałaga, M. Mokrowiecka, A. Zakrzewski, P. K. Cygankiewicz, A. Leishman, E. Sobczak, M. Zatorski, H. Małecka-Panas, E. Kordek, R. Storr, M. Krajewska, W. M. Bradshaw, H. B. \&, J. (2014). Experimental colitis in mice is attenuated by changes in the levels of endocannabinoid metabolites induced by selective inhibition of fatty acid amide hydrolase (FAAH). J. Crohns Coliti, 8(9), 998-1009. 